Article

\title{
Ultramicrobacteria from Nitrate- and Radionuclide-Contaminated Groundwater
}

\author{
Tamara Nazina ${ }^{1,2, *(D)}$, Tamara Babich ${ }^{1}$, Nadezhda Kostryukova ${ }^{1}$, Diyana Sokolova ${ }^{1}$, \\ Ruslan Abdullin 1, Tatyana Tourova 1, Vitaly Kadnikov ${ }^{3}$, Andrey Mardanov ${ }^{3}$, Nikolai Ravin ${ }^{3}$, \\ Denis Grouzdev ${ }^{3}$ (D), Andrey Poltaraus ${ }^{4}$, Stepan Kalmykov ${ }^{5}$, Alexey Safonov ${ }^{6}$, \\ Elena Zakharova ${ }^{6}$, Alexander Novikov ${ }^{2}$ and Kenji Kato ${ }^{7}$
}

1 Winogradsky Institute of Microbiology, Research Center of Biotechnology, Russian Academy of Sciences, 119071 Moscow, Russia; microb101@yandex.ru (T.B.); npavlova@mail.ru (N.K.); sokolovadiyana@gmail.com (D.S.); rusfbm@gmail.com (R.A.); tptour@rambler.ru (T.T.)

2 V.I. Vernadsky Institute of Geochemistry and Analytical Chemistry of Russian Academy of Sciences, 119071 Moscow, Russia; novikov@geokhi.ru

3 Institute of Bioengineering, Research Center of Biotechnology of the Russian Academy of Sciences, 119071 Moscow, Russia; vkadnikov@bk.ru (V.K.); andrey.mardanov@gmail.com (A.M.); nravin@mail.ru (N.R.); denisgrouzdev@gmail.com (D.G.)

4 Engelhardt Institute of Molecular Biology, Russian Academy of Sciences, 119071 Moscow, Russia; abpolt@gmail.com

5 Chemical Faculty, Lomonosov Moscow State University, 119991 Moscow, Russia; stepan@radio.chem.msu.ru

6 Frumkin Institute of Physical Chemistry and Electrochemistry, Russian Academy of Sciences, 119071 Moscow, Russia; alexeysafonof@gmail.com (A.S.); zakharova@ipc.rssi.ru (E.Z.)

7 Faculty of Science, Department of Geosciences, Shizuoka University, 422-8529 Shizuoka, Japan; kato.kenji@shizuoka.ac.jp

* Correspondence: nazina@inmi.ru; Tel.: +7-499-135-03-41

Received: 24 January 2020; Accepted: 6 February 2020; Published: 8 February 2020

check for updates

\begin{abstract}
The goal of the present work was to investigate the physicochemical and radiochemical conditions and the microbial diversity in groundwater collected near the Lake Karachai (Russia), which was formerly used for the disposal of liquid radioactive waste, to isolate the dominant bacteria, and to determine their taxonomy and the physiological characteristics responsible for their adaptation to this environment. Groundwater samples contained high concentrations of acetate, oxalate, nitrate, and sulfate, as well as radionuclides. High-throughput sequencing and analysis of the clone libraries revealed lower microbial diversity in the most strongly contaminated groundwater and a predominance of bacteria of the genera Polynucleobacter, Pusillimonas, Candidatus Pelagibacter, and of the candidate phylum Parcubacteria; these groups include species with an ultra small cell size. Archaeal sequences in the libraries belonged to ammonium oxidizers of the phylum Thaumarchaeota and methanogens of the phylum Euryarchaeota. Pure cultures of obligate and facultative ultramicrobacteria belonging to the genera Chryseobacterium, Microbacterium, Salinibacterium, Pusillimonas, Roseomonas, and Janibacter were isolated from water samples. In genomes of Pusillimonas and Roseomonas strains the genes associated with nitrate reduction, resistance to heavy metals and metalloids were revealed. Several isolates are able to participate in the geochemical process of nitrate conversion to $\mathrm{N}_{2}$ using acetate; this results in decreasing redox potential, which in turn may stimulate radionuclide reduction and decrease radionuclide migration in groundwater.
\end{abstract}

Keywords: nitrate- and radionuclide-contaminated groundwater; $16 \mathrm{~S}$ rRNA gene; pyrosequencing; ultramicrobacteria; Chryseobacterium; Pusillimonas; Salinibacterium; Janibacter 


\section{Introduction}

According to the modern concept, ultra-microbacteria are characterized by (1) ultra small sizes (the volume of less than $0.1 \mu \mathrm{m}^{3}$ for most cells in the populations); (2) maintenance of ultra small cell size regardless of the growth conditions and culture development stage; and (3) small genome size $(\sim 3.2$ to $\sim 0.58 \mathrm{Mb})[1,2]$. The majority of oligotrophic bacteria found in freshwater and marine environment are planktonic and have small cell volumes $\left(<0.1 \mathrm{~mm}^{3}\right)$ [3]. Ultra-microbacteria are responsible for the major part of the biomass and metabolic activity in oceanic ecosystems, and express higher metabolic activity per unit of volume of seawater than larger bacterial cells [3]. Unlike copiotrophs that become small as a result of reductive cell division, oligotrophic ultra-microbacteria retain a small volume of cells even during the life cycle. Subsurface water and sediments not associated with petroleum, peat, or coal deposits are also a freshwater oligotrophic environment [4]. An inflow of organic and mineral contaminants to subsurface water can selectively increase the activity and abundance of microorganisms. The microbial populations of groundwater contaminated by radioactive waste are of special interest, since they may affect the valency and mobility of uranium and other variable-valency elements. While occurrence of bacteria with small genomes and ultra small cells in groundwater has been reported [5,6], culturable filterable bacteria isolated from subsurface horizons remain scarcely studied.

The first report of phylogenetic diversity of microorganisms with ultra small cells in deep environments was presented by Mioshi et al. [7] for anaerobic groundwater of the Tono uranium mine, Japan. The bacteria passing through the membranes with $0.22-\mu \mathrm{m}$ pores belonged to the class Betaproteobacteria, while uncultured small-celled bacteria of the candidate groups OD1 and OP11 passed through the filters with $0.1-\mu \mathrm{m}$ pores. The genomes of OD1 and OP11 bacteria were retrieved from fresh and brackish water samples and hydrothermal sites [8]. Based on single-cell genomic data, candidate Bacterial phyla OD1 and OP11 were assigned to the candidate phyla Parcubacteria and Microgenomates, respectively, of the superphylum 'Patescibacteria' [9]. Near-complete genome sequences of Parcubacteria (OD1) were obtained using metagenomic analysis of DNA from anoxic groundwater samples from an aquifer near Rifle, CO, USA [5,6]. Storage of uranium mill tailings at the Rifle alluvial aquifer site resulted in formation of a groundwater uranium plume [10]. Nelson and Stegen [11] reconstructed eight OD1 genomes from oxic groundwater samples from Hanford 300 Area at the Rifle. The organisms had small genomes (generally $<1 \mathrm{Mb}$ ) missing the genes associated with biosynthetic capabilities and DNA repair, but containing the genes potentially encoding the attachment and adhesion proteins, which indicated that "the Parcubacteria were ectosymbionts or parasites of other organisms". Anaerobic ultra Microbacterium 'Dehalobium chlorocoercia' DF-1 able to dechlorinate polychlorinated biphenyl using $\mathrm{H}_{2}$ and formate as electron donors was isolated from marine sediments of Charleston Harbor [12]. The genomes of Nanoarchaea with small size and limited metabolic capacity, which were probably involved in anaerobic carbon and hydrogen cycles, were reconstructed from an aquifer near Rifle, CO, USA also [13].

Sequences of the 16S rRNA genes both of the cultured members of the phyla Proteobacteria, Dehalococcoides, Actinobacteria, Acidobacteria, Firmicutes, Bacteroidetes, Planctomycetes and of uncultured bacteria of Candidate divisions OD1, OP3 and OP11 were revealed in clone libraries of microorganisms from groundwater of a disposal site for liquid radioactive wastes at the Siberian Chemical Complex (SCC, Tomsk-7, or Seversk, Russia) [14].

Advances in metagenomics, single-cell genome analysis, and metatranscriptomics promoted an increase in our knowledge of the genetics of uncultured microorganisms. However, investigation of pure cultures remains essential for correlation of the results of metagenomic analysis and the physiological and genomic characteristics of cultured microorganisms.

In the present work, the microorganisms of groundwater from the Lake Karachai region, one of the most contaminated basins in the world, are investigated. Since 1951, Lake Karachai (V-9 industrial reservoir) was used for storage of liquid intermediate-level nuclear wastes at the Production Association "Mayak" (PA "Mayak"), the first Russian plant producing plutonium, located in the north 
of the Chelyabinsk region [15]. PA "Mayak" activity resulted in a local accumulation of large quantities of wastes coming from radiochemical technology and in radioactive contamination of some parts of the neighboring regions by long-lived radionuclides, mainly ${ }^{90} \mathrm{Sr}$ and ${ }^{239} \mathrm{Pu}$ [16]. The effluent discharged into the Lake Karachai consisted of radioactive, slightly alkaline ( $\mathrm{pH}$ 7.9-9.3) brine with density between 1.006 and $1.095 \mathrm{~g} / \mathrm{cm}^{3}$; the dissolved salt varied from 16 to $145 \mathrm{~g} / \mathrm{L}$. The major components of the waste were nitrate, acetate, oxalate, sulfate, and sodium [17]. Waste effluents were enriched with $\mathrm{Fe}, \mathrm{Al}, \mathrm{Zr}$, and rare earth elements. Long-term exploitation of V-9 reservoir resulted in large-scale groundwater contamination in the area, which was caused by infiltration of radioactive solutions through the permeable bottom of the reservoir in different directions. The radioactivity of ${ }^{90} \mathrm{Sr},{ }^{106} \mathrm{Ru}$ and ${ }^{137} \mathrm{Cs}$ in the 50-100-m deep water horizon was 20-300 times lower than in the waters of the V-9 reservoir, and $\mathrm{NO}_{3}{ }^{-}$concentration in the plum under the reservoir was 3.5-5 times higher than that in the water of the V-9 reservoir. In 2015, the Lake Karachai was filled with sand and covered with concrete and rock plates.

The high level of nitrate in the groundwater in the Karachai area prevents reductive immobilization of uranium. Denitrification intermediates (nitrite, nitric oxide, and nitrous oxide) are known to be capable of oxidizing and mobilizing U(IV) abiotically [18]. The removal of nitrate favored reduction of oxidized radionuclides and decreased their migration [18,19]. Geochemical evidence for denitrification in groundwater in the Karachai area is available [20], but the detection of microorganisms capable of nitrate reduction is a necessary stage for prediction of behavior of nitrate and radionuclides in contaminated subsurface waters.

The analysis of clone libraries of the 16S rRNA genes of microorganisms from groundwater of the Karachai area resulted in the retrieval of the sequences of uncultured bacteria of the candidate phylum OD1 (or Parcubacteria), Polynucleobacter sp. and 'Candidatus Pelagibacter sp.' with small-sized cells [21]. Over 50 strains of aerobic organotrophic and anaerobic denitrifying and iron-reducing bacteria belonging to 23 genera and 33 species were isolated from the samples. Further research on the composition of the microbial community and on the ecologically possible functions of the obtained pure cultures was essential.

The goal of the present work was to investigate the physicochemical and radiochemical conditions and the microbial community composition in nitrate- and radionuclide-contaminated groundwater collected near Lake Karachai (Russia), to isolate bacteria, including those with ultra-small cell size, and to determine the taxonomic position, physiological, and genomic characteristics responsible for their adaptation to this environment.

\section{Materials and Methods}

\subsection{Sampling of Groundwater}

Groundwater was sampled from the southern limb of the contamination plume in the PA "Mayak" industrial area. The samples were collected from observation wells (20-80 m deep), 2.0-3.2 km from Lake Karachai. Groundwater samples for microbiological analysis were collected into sterile bottles using an electrical pump and sealed hermetically. The samples for chemical and radiochemical studies were collected into 20-L bottles under nitrogen atmosphere to avoid contact with air. The samples for microbiological studies were collected into sterile 1-L bottles and hermetically sealed; samples for molecular studies were collected into 3-L bottles, each containing $0.75 \mathrm{~L}$ ethanol. The samples were transported to the laboratory in hermetic bottles for filtration and analysis.

\subsection{Microbial Enumeration and Isolation}

Numbers of anaerobic denitrifying, fermenting, iron- and sulfate-reducing, and methanogenic prokaryotes were estimated using the MPN technique with two replicates for each tenfold dilution of groundwater samples as described previously [14]. Aerobic organotrophs were enumerated in the TEG medium containing the following ( $\mathrm{g} \mathrm{L}-1$ distilled water): bacto-tryptone, 5.0; yeast extract, 2.5; glucose, 
1.0; $\mathrm{pH}$ 7.0. Aerobic lithoautotrophic ammonium-oxidizing bacteria were revealed by inoculation of undiluted groundwater samples to the DSM medium 1583 (https://www.dsmz.de/microorganisms/ medium/pdf/DSMZ_Medium1583.pdf). $\mathrm{NO}_{2}{ }^{-}$production was detected with the Griess reagent by development of pink color. Lithoautotrophic nitrite-oxidizing bacteria were incubated in the medium containing per liter distilled water: $1 \mathrm{~g} \mathrm{NaNO}_{2}, 0.5 \mathrm{~g} \mathrm{~K}_{2} \mathrm{HPO}_{4}, 0.5 \mathrm{~g} \mathrm{MgSO}_{4} 7 \mathrm{H}_{2} \mathrm{O}, 0.5 \mathrm{~g} \mathrm{NaCl}$; $0.4 \mathrm{~g} \mathrm{FeSO}_{4} 7 \mathrm{H}_{2} \mathrm{O} ; 1.0 \mathrm{~g} \mathrm{Na}_{2} \mathrm{CO}_{3} ; \mathrm{pH}$ 8.0-9.2. $\mathrm{NO}_{3}{ }^{-}$production was detected with diphenylamine by development of blue color. Inoculated media were incubated at room temperature $\left(18-24{ }^{\circ} \mathrm{C}\right)$ until the onset of growth, but no longer than 30 days. All the cultures were then examined under an Axio Imager.D1 epifluorescence microscope (Carl Zeiss, Oberkochen, Germany), and specific microbial metabolites were analyzed.

Enrichment cultures of aerobic organotrophic and denitrifying bacteria obtained in our experiments were used for isolation of pure cultures by successive transfer from liquid media to respective solid media. Search for ultramicrobacteria in the samples was also carried out. For this purpose, groundwater (20-40 mL) was filtered through $0.45-$ and $0.22-\mu \mathrm{m}$ pore size membrane filters (Whatman, Maidstone, UK). The filtrate was used to inoculate low-nutrient AMS1 medium with methionine, glycine, pyruvate, vitamins and inorganic salts, as recommended for the growth of 'Candidatus Pelagibacter ubique' [22]. To exclude the development of rapidly growing bacteria, the cultures were incubated for 7-14 days in a refrigerator at $6-8{ }^{\circ} \mathrm{C}$, then at room temperature $\left(18-22^{\circ} \mathrm{C}\right)$, and then transferred onto solid media of relevant composition. Sequential transfers from liquid to solid media resulted in isolation of pure cultures of filterable bacteria. Single colonies were used for microbiological and molecular studies. Such characteristics of strains as temperature and $\mathrm{pH}$ ranges and optima for growth, $\mathrm{NaCl}$ tolerance, catalase activity, anaerobic growth, nitrate reduction, acid production, and growth with various substrates were tested as described by Smibert and Krieg [23].

\subsection{Microscopy}

Cell morphology of the isolates was examined using a JEOL JEM-1011 (JEOL Ltd., Tokyo, Japan) transmission electron microscope at accelerating voltage of $80 \mathrm{kV}$. The cells were contrasted with $2 \%$ phosphotungstic acid. For ultrathin sectioning, cells were harvested by centrifugation and then fixed in a solution of $1.5 \%(w / v)$ glutaraldehyde in $0.05 \mathrm{M}$ cacodylate buffer $(\mathrm{pH} 7.2)$ at $4{ }^{\circ} \mathrm{C}$ for $1 \mathrm{~h}$. The cells were washed three times in the same buffer and post-fixed in $1 \% \mathrm{OsO}_{4}$ in $0.05 \mathrm{M}$ cacodylate buffer ( $\mathrm{pH} 7.2$ ) for $3 \mathrm{~h}$ at $20{ }^{\circ} \mathrm{C}$. The preparation was dehydrated in a series of increasing ethanol concentrations, in acetone and embedded in Epon 812 epoxy resin. Ultrathin sections were mounted on grids, post-stained with $3 \%(w / v)$ uranyl acetate in $70 \%(v / v)$ ethanol for $30 \mathrm{~min}$, and afterwards additionally stained with lead citrate according to Reynolds [24]. Thin sections were examined in a JEOL JEM-100 transmission electron microscope at an acceleration voltage of $80 \mathrm{kV}$.

\subsection{Identification of Pure Cultures}

Pure bacterial cultures were identified by analysis of their $16 \mathrm{~S}$ rRNA gene sequences. DNA isolation, amplification, and sequencing of the 16S rRNA genes were carried out as described previously [25]. The full-sized 16S rRNA gene was amplified using the $8 \mathrm{f}-1492 \mathrm{r}$ primers and was used as a template for DNA sequencing with the primers 8f, 519r, 519f, and 1492r. Preliminary analysis of the 16S rRNA gene sequences was carried out using the Ribosomal Database Project (RDP, http://rdp.cme.msu.edu) data and software. The sequences were edited using BioEdit (http: //jwbrown.mbio.ncsu.edu/BioEdit/bioedit.html) and aligned with those of closely related Bacterial species using MAFFT 7.427 [26].

\subsection{Analytical Methods}

Molecular hydrogen, nitrogen, and methane produced by microorganisms were analyzed by gas chromatography using approaches described previously [14]. Sulfide was determined with dimethyl-p-phenylenediamine by a modified colorimetric method of Pachmayr [27]. The values 
of $\mathrm{pH}$, Eh, and total salinity of groundwater were measured using a HITON-S hydrogeochemical sampler (LLC Scientific and Production Center Pals, Samara, Russia) equipped with selective electrodes; the sampler was submerged into the wells and the parameters at an examined depth were recorded. Iron, magnesium, calcium, and sodium in groundwater were analyzed on an AASIN atomic absorption spectrophotometer (Carl Zeiss, Jena, Germany). Nitrate was analyzed on an Ecotest-01 device (NPP Econiks, Moscow, Russia) with an ELIT-21 (NPP Econiks, Moscow, Russia) ion-selective electrode. Nitrite was determined colorimetrically with sulfanilic acid and $\alpha$-naphthylamine [28]. Other components of groundwater were analyzed as described earlier [29]. Radiochemical procedures for speciation of actinides in the environment were described previously [30].

\subsection{Radiotracer Methods and Tolerance to Heavy Metals and Ionizing Radiation}

The rates of sulfate reduction and methanogenesis in groundwater were determined by radiotracer methods using labeled $\mathrm{Na}_{2}{ }^{35} \mathrm{SO}_{4},{ }^{14} \mathrm{CH}_{3} \mathrm{COONa}$, and $\mathrm{NaH}^{14} \mathrm{CO}_{3}$ according to the method employed by Nazina et al. [31]. Aliquots of formation water were incubated with labeled substrates for 24-48 h at $22{ }^{\circ} \mathrm{C}$.

Stock solutions of $1.0 \mathrm{~g} \mathrm{~L}^{-1} \mathrm{CdSO}_{4} 8 \mathrm{H}_{2} \mathrm{O}, 2.0 \mathrm{~g} \mathrm{~L}^{-1} \mathrm{~K}_{2} \mathrm{Cr}_{2} \mathrm{O}_{7}, 2.0 \mathrm{~g} \mathrm{~L}^{-1} \mathrm{Zn}\left(\mathrm{NO}_{3}\right)_{2} 6 \mathrm{H}_{2} \mathrm{O}, 2.0 \mathrm{~g} \mathrm{~L}^{-1}$ $\mathrm{CuSO}_{4} 6 \mathrm{H}_{2} \mathrm{O}$, and $2.0 \mathrm{~g} \mathrm{~L}^{-1} \mathrm{UO}_{2}\left(\mathrm{NO}_{3}\right)_{2} 6 \mathrm{H}_{2} \mathrm{O}$ were sterilized at $121^{\circ} \mathrm{C}$ for $15 \mathrm{~min}$, and aseptically added into the sterilized liquid TEG medium supplemented with $5 \%(w / v) \mathrm{NaCl}$ to prepare selective media containing 10, 50, 100, 200, and $300 \mathrm{mg} \mathrm{L}^{-1} \mathrm{Cd}^{2+} ; 25,100,200,300$, and $400 \mathrm{mg} \mathrm{L}^{-1} \mathrm{Cr}^{6+} ; 10,25,50,100$, and $200 \mathrm{mg} \mathrm{L}^{-1} \mathrm{Cu}^{2+} ; 10,25,50,100$, and $200 \mathrm{mg} \mathrm{L}^{-1} \mathrm{Zn}^{2+}$; and 10, 100, 200, 300, and $400 \mathrm{mg} \mathrm{L}^{-1} \mathrm{U}^{6+}$, respectively. Media containing series of concentrations of heavy metals were inoculated with isolated strains and incubated at $24^{\circ} \mathrm{C}$ for 24 days. After incubation, the total cell numbers were determined by light microscopy. The numbers of living and dead cells were determined by staining with the LIVE/DEAD ${ }^{\circledR}$ BacLight ${ }^{\mathrm{TM}}$ Bacterial Viability Kit for microscopy \& quantitative assays according to the recommendations (https:/www.thermofisher.com/order/catalog/product/L7012) under a Microoptix MX 300 light microscope (West Medica Production und Handels-GmbH, Perchtoldsdorf, Austria) with an epifluorescence block. Inoculated media without metals were used as the controls.

Radioresistance of exponentially growing cultures of strains JR1/69-1-13, JR1/69-2-13, and JR1/69-3-13 was determined using an YELV-10-10-S-70 electron accelerator with beam energy $10 \pm 0.4 \mathrm{MeV}$ and beam current $500 \pm 0.4 \mu \mathrm{A}$ (IPCE RAS). For irradiation we used different radiation doses $(0.1,0.5,1.0,5.0,10.0,15.0$ and $25.0 \mathrm{kGy})$ with dose rate $0.3 \mathrm{kGy} / \mathrm{min}$ and radiation doses 10.0, 15.0 and $25.0 \mathrm{kGy}$ with dose rate $3 \mathrm{kGy} / \mathrm{min}$. Radiation doses were controlled using a Fricke ferrous sulfate dosimeter; for doses below $5 \mathrm{kGy}$, the radiation dose was controlled by Radiochromic film dosimeters SO PD(F)R 5/50 and SO PD(E) 1/10 FSUE "VNIIFTRI".

The cell suspensions in tubes with $10 \mathrm{~mL}$ of TEG medium closed with rubber stoppers were exposed to radiation for predetermined times. At each time-point, three individual aliquots of each strain were removed from the radiation source. The effect of radiation on the microorganisms was assessed $60 \mathrm{~min}$ after irradiation according to the respiratory activity of living cells in the same test tubes (acute experiment), which was determined by staining with MTT (3-(4,5-dimethylthiazol-2-yl)-2,5-diphenyltetrazolium bromide) with subsequent extraction of produced formazan by dimethyl sulfoxide (DMSO) and measuring the extract optical density at 500-600 nm, as was proposed previously $[32,33]$. The results were calculated as percentages of the respiratory activity in the control samples. The experiment was carried out in three replicates. Resistance of bacteria to heavy metals and ionizing radiation was determined by the standard approaches using semilethal $\left(\mathrm{LD}_{50}\right)$ and lethal doses $\left(\mathrm{LD}_{100}\right)$.

\subsection{Construction and Analysis of the $16 S$ rRNA Gene Clone Libraries}

DNA Extraction: Groundwater samples from the observation wells 1/69 (from the depth $44 \mathrm{~m}$ ), 2/68 (80 m), and 14/68 (80 m) (each 2.25 L) were fixed with ethanol (each with $0.75 \mathrm{~L}$ ) immediately after sampling and were passed through $0.22-\mu \mathrm{m}$ membrane filters. Prior to analysis, the filters with biomass 
were stored at $-20^{\circ} \mathrm{C}$. The total DNA was isolated from the filters using DiatomTM DNAprep kit for DNA isolation (Shemyakin and Ovchinnikov Institute of Bioorganic Chemistry, Russian Academy of Sciences, Moscow, Russia) as described earlier [14]. For total DNA isolation, the cell pellet was suspended with guanidine hydrochloride at $65{ }^{\circ} \mathrm{C}$ for $60 \mathrm{~min}$. The sorbent (Diatomid/silica) was added to the cell lysate. After DNA sorption, the supernatant was removed and the sorbent was washed using $70 \%(v / v)$ ethanol. The total DNA preparation was dissolved in $100 \mu \mathrm{L} \mathrm{H}_{2} \mathrm{O}(\mathrm{MQ})$ and used for $16 \mathrm{~S}$ rRNA gene amplification and microbial community analysis by cloning or/and high-throughput sequencing.

The 16S rRNA gene amplification, cloning, and sequencing of cloned fragments of the 16S rRNA genes: Isolated DNA obtained from observation wells 1/69, 2/68 and 14/68 was amplified by PCR using the primers specific for bacteria (8-27f, and 1492r) [34,35] and Archaea (A8F, A109f, A517R, A800f, and A1041r') [36,37]. The amplicons were separated using $0.8 \%$ agarose gel, stained with ethidium bromide, and visualized under UV illumination. For PCR product purification, the fragments were excised from the gel, and the DNA was extracted using a V-gene DNA Gel Extraction Kit (V-gene Biotechnology Ltd. Hangzhou 310022, China) with subsequent precipitation of the DNA fragments by $70 \%$ ethanol and $0.3 \mathrm{M} \mathrm{CH}_{3} \mathrm{COONa}$. Bacterial and archaeal 16S rRNA genes were purified and cloned into the pTZ57RT plasmid vector (Fermentas, Vilnius, Lithuania). The clones containing the DNA inserts were sequenced using the plasmid primers M13D and M13R. The sequencing was performed on a 3730 DNA Analyzer using BigDye ${ }^{\circledR}$ Terminator v3.1 Cycle Sequencing Kit (Applied Biosystems, Foster City, CA, United States), in compliance with the recommendations of the manufacturers.

Phylogenetic analysis of the 16S rRNA gene sequences: The sequences were homology-searched using the NCBI BLAST software package (http://www.ncbi.nlm.nih.gov/blast) and SILVA (http: //www.arb-silva.de). The sequences were edited using the BioEdit software package (http://jwbrown. mbio.ncsu.edu/BioEdit/bioedit.html). The sequence data were aligned with the sequences retrieved from the GenBank database using the MAFFT 7.427 [26], with the clones with at least 98\% similarity grouped into operational taxonomic units (OTUs) or phylotypes. Detection of the chimeras and checking for the secondary structure anomalies was carried out using the CHIMERA-CHECK program from the Ribosomal Database Project.

Pyrosequencing of $16 \mathrm{~S}$ rRNA amplicons and data analysis: The filtered cells from $2.25 \mathrm{~L}$ of groundwater taken from observation well 176/94 yielded $1656 \mathrm{ng}$ of DNA. $10 \mathrm{ng}$ of DNA was used for amplification of the 16S rRNA gene fragment comprising V3-V8 variable regions: U341F (5' -CCT ACG GGR BGC ASC AG) and E1406R (5'-GAC GGG CGG TGW GTR CA). The PCR fragments were sequenced with a Roche Genome Sequencer (GS) FLX, using the XL+ protocol. The 16S rRNA gene sequences determined by pyrosequencing were subjected to the standard filter for environmental pyrosequencing datasets and selected for tags that displayed perfect matches to the primers and contained no ambiguous nucleotides. The $16 \mathrm{~S}$ rRNA reads starting from primer U341F were used for further analysis. The 16S rRNA gene data were analyzed using the RPD Classifier program package [38]. As a first step, the sequences were distributed between bacteria and archaea using the online RDP Naive Bayesian rRNA Classifier version 2.0 (http://rdp.cme.msu.edu/index.jsp). Then, Bacterial and archaeal data sets were analyzed separately.

Bacterial and archaeal 16S rRNA gene fragments were processed using a combination of QIIME [39] and USEARCH [40] pipelines. After demultiplexing and quality control, the sequences were de-replicated and chimeras and singletons were removed. The resulting datasets upon filtration consisted of $11768516 \mathrm{~S}$ rRNA reads assigned to bacteria and 104 reads assigned to Archaea. The sequences were de novo clustered into OTUs as having $\geq 98 \%$ sequence identity using QIIME. Taxonomic assignment of each OTU was accomplished using the online RDP Classifier (https://pyro.cme.msu.edu/classifier/form.spr).

Statistical Analysis. Alpha diversity metrics were calculated using the QIIME [39]. ClustVis was employed to generate the heat map of most abundant genera [41]. 


\subsection{Genome Analysis}

Genomes of Pusillimonas sp. JR1/69-2-13, Pusillimonas sp. JR1/69-3-13 and Roseomonas aestuarii JR1/69-1-13 were sequenced and annotated as described previously [42,43]. Identification of protein-coding sequences and primary annotation was performed using the NCBI Prokaryotic Genome Automatic Annotation Pipeline (PGAAP) [44]. Additional gene prediction and functional annotation were performed in the Rapid Annotation using Subsystems Technology (RAST) server [45] and Integrated Microbial Genome-Expert Review pipeline [46], respectively. The analysis of metal resistance was performed with the AntiBacterial Biocide and Metal Resistance Genes Database (BacMet) [47].

\subsection{Nucleotide Sequence Accession Numbers}

The sequences of the 16S rRNA genes of microorganisms from libraries 1/69, 2/68, 14/68 and 176/94 were submitted to the GenBank/DDBJ/EMBL databases as BioProject: PRJNA548669 (http://www.ncbi. nlm.nih.gov/bioproject/548669). The draft genome sequences of strains Pusillimonas sp. JR1/69-2-13, Pusillimonas sp. JR1/69-3-13 and R. aestuarii JR1/69-1-13 are available at DDBJ/EMBL/GenBank under the accession nos. https://www.ncbi.nlm.nih.gov/nuccore/PDNV00000000, https://www.ncbi.nlm. nih.gov/nuccore/PDNW00000000, and https://www.ncbi.nlm.nih.gov/nuccore/NZ_PDOA00000000. 1 , respectively.

\section{Results}

\subsection{Physicochemical, Radiochemical, and Microbiological Characteristics of Groundwater}

Environmental conditions and an abundance of the major microbial physiological groups were studied in groundwater samples collected in the vicinity of Lake Karachai (industrial reservoir V-9), which was used as a repository of liquid radioactive waste at the PA "Mayak" area. The studied groundwater samples had high redox values (Eh from +110 to $+420 \mathrm{mV}$ ), $\mathrm{pH}$ from 6.9 to 8.0 , and elevated total salinity and radionuclide content (Table 1). Chloride, sulfate, nitrate, and acetate were the major anions. The concentrations of nitrate, acetate, and carbonate varied from 120 to $42,700 \mathrm{mg} \mathrm{L}^{-1}$, from 26 to $921 \mathrm{mg} \mathrm{L}^{-1}$, and from 59 to $1820 \mathrm{mg} \mathrm{L}^{-1}$, respectively. Uranium and americium concentrations were below the relevant intervention levels (IL) by Radiation safety standards (NRB-99/2009) of Russian Federation regulation, while strontium concentration exceeded IL of $5.0 \mathrm{~Bq} / \mathrm{dm}^{3}$. Temperature of the studied groundwater in the Karachai area was $6-7^{\circ} \mathrm{C}$ [48].

Groundwater samples were found to contain cultivated aerobic organotrophic $\left(10-10^{5}\right.$ cells $\left.\mathrm{mL}^{-1}\right)$ and nitrifying prokaryotes, as well as anaerobic fermenting $\left(10-10^{5}\right.$ cells $\left.\mathrm{mL}^{-1}\right)$, denitrifying $\left(0-10^{4}\right.$ cells $\left.\mathrm{mL}^{-1}\right)$, and iron-reducing bacteria $\left(0-10^{3}\right.$ cells $\left.\mathrm{mL}^{-1}\right)$ (Figure A1). The numbers of sulfate-reducing $(<10$ cells $\left.\mathrm{mL}^{-1}\right)$ and methanogenic prokaryotes $\left(0-10^{2}\right.$ cells $\left.\mathrm{mL}^{-1}\right)$ were very low, and sensitive radiotracer measurements with labeled $\mathrm{Na}_{2}{ }^{35} \mathrm{SO}_{4},{ }^{14} \mathrm{CH}_{3} \mathrm{COONa}$, and $\mathrm{NaH}^{14} \mathrm{CO}_{3}$ revealed no sulfate reduction and methanogenesis in most of the studied samples (Table 1).

\subsection{Phylogenetic Diversity of Archaea and Bacteria in Groundwater Samples}

DNA extracted from groundwater samples collected at weakly contaminated (wells 1/69 and 176/94) and strongly contaminated zones (wells 2/68 and 14/68) was used for cloning of the 16S rRNA genes and pyrosequencing by means of the 454 platform (Table A1). Diversity indices for archaeal components in the library 176/94 obtained by pyrosequencing and in the clone libraries 1/69 and 2/68 were similar, while cloned sequences from the library 14/68 exhibited low diversity and domination of a small number of phylotypes (Table A2). Diversity indices of bacteria were significantly higher in the library 176/94 than in all clone libraries, especially the library $14 / 68$, in which the dominance index was 0.97 , indicating that this library was almost completely represented by a single phylotype. 
Table 1. Chemical and radiochemical composition of the groundwater samples obtained in the Karachai region and rates of sulfate reduction (SR) and methanogenesis (MG).

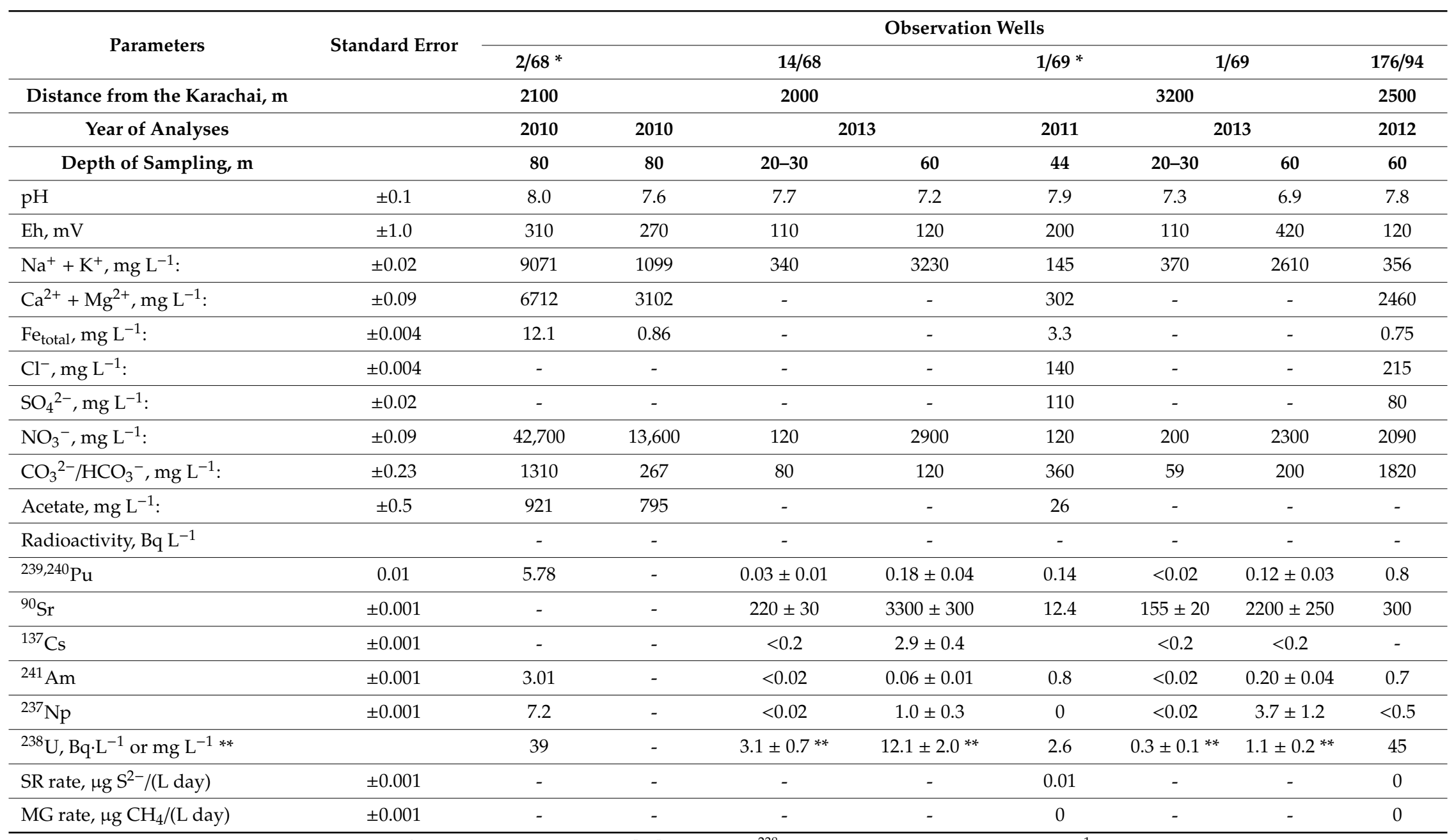

${ }^{*}$ Data from the paper Nazina et al. [21]. ${ }^{* *}$ Content ${ }^{238} \mathrm{U}$ in the groundwater sample in $\mathrm{mg} \mathrm{L}^{-1}$. 
The share of archaeal 16S rRNA gene sequences in the 176/94 library did not exceed $0.5 \%$, and their OTUs (phylotypes) were represented mainly by the sequences of Thaumarchaeota belonging to autotrophic ammonium-oxidizing archaea of the genera Nitrosopumilus $(30.7 \%)$ and Nitrososphaera (21.2\%), uncultured Pacearchaeota (42.3\%), and Euryarchaeota (5.8\%), belonging to methanogens of the genera Methanoregula and Methanothrix (Figures 1a and A2a, Table A1). A similar archaeal composition was revealed in the clone library from well $1 / 69$. In the libraries from highly contaminated groundwater from wells 2/68 and 14/68, the sequences of ammonium-oxidizing Thaumarchaeota (Nitrosopumilus and Nitrososphaera) were numerically predominant.

Thus, nitrate-contaminated groundwater was inhabited by archaea involved in the nitrogen cycle, as well as by uncultured Pacearchaeota $(42.3 \%)$ characterized by small genomes and involved in anaerobic carbon and hydrogen metabolism, probably associated with symbiotic and/or fermentation-based lifestyles [13].

Cloned sequences of Bacterial 16S pPHK genes in the libraries 14/68, 2/68, and 1/69 belonged to 4,60 , and 16 phylotypes, respectively, while the more representative library 176/94 obtained by pyrosequencing was found to contain 927 phylotypes of the species level. Proteobacteria sequences accounted for 35.2 to $97.1 \%$ of total number of sequences in the libraries (Figures $1 b$ and A2b, Table A1). Among the Proteobacteria sequences, those of the Beta-, Alpha-, and Gammaproteobacteria were the most numerous.

Other phyla revealed in the libraries from contaminated groundwater were Candidatus Parcubacteria (former OD1, 34.5\%), which include bacteria with ultra-small size of cells and reduced metabolic capacities [9], Bacteroidetes (10.0\%), Chloroflexi (10.7\%), and Firmicutes (3.5\%).

Members of the genus Pusillimonas were responsible for 18.2 and $97.1 \%$ of sequences in the libraries of highly contaminated groundwater from wells $2 / 68$ and 14/68, respectively. Other numerous phylotypes belonged to bacteria affiliated with the candidate phylum Parcubacteria (34.5\%), uncultured Coxiellaceae (30.9\%), and genera Polynucleobacter (14.3\%), Frigidibacter, Levilinea, Curvibacter, Lysobacter, Nitrospira, Rhodoferax, Gallionella, Sideroxydans, Simplicispira, Hydrocarboniphaga, Sulfuritalea, and Reyranella (Figure 1b, Table A1). Bacteria of the genera Pusillimonas, Polynucleobacter, Microbacterium, Chryseobacterium, 'Candidatus Pelagibacter,' and the candidate phylum Parcubacteria include species with small or ultra-small size of the cells (Figure 1b, Table A1).

\subsection{Isolation and Taxonomy of Bacteria from Groundwater}

Since the 16S rRNA gene libraries contained the sequences of uncultured bacteria such as 'Candidatus Pelagibacter', search for bacteria with small and ultra-small cells and their isolation were necessary. Groundwater samples were sequentially filtered through the filters with 0.45 - and $0.22-\mu \mathrm{m}$ pores. The latter filtrate was inoculated into the low nutrient medium for 'Candidatus Pelagibacter ubique' and using an approach recommended by [22] as "selective filtration enrichment procedure and long-term incubations at low temperatures", we isolated six strains of small-celled bacteria. Based on analysis of their 16S rRNA gene sequences, filterable microorganisms were affiliated with phyla Actinobacteria and Bacteroidetes. Four strains were assigned to Janibacter limosus (strain JR43/78-4-13, $99.7 \%$ similarity with the 16S rRNA gene of the type strain of the species), Microbacterium oxydans (JR3/2-13, 99.6\%), Paeniglutamicibacter sulfureus (JR1/1-8b, 99.3\%), and Mycolicibacterium iranicum (JR2/2-1, $100 \%$ ). The $16 \mathrm{~S}$ rRNA gene sequences of strains J1-13Tb and JR2/1-6 had 98.2 and $98.5 \%$ similarity with those of the type strains Chryseobacterium haifense $\mathrm{H}_{3} 8^{\mathrm{T}}$ and Salinibacterium amurskyense $\mathrm{KMM}$ $3673^{\mathrm{T}}$, respectively. These values were below $98.65 \%$, the threshold for differentiating two species [49]. Thus, strains J1-13Tb and JR2/1-6 probably belong to two new species. Attempts to isolate the target bacterium 'Candidatus Pelagibacter ubique' proved unsuccessful. Five strains were isolated on media for aerobic and denitrifying bacteria without the filtration stage. Three strains were assigned to known species Roseomonas aestuarii (JR1/69-1-13, 99.6\%), Rhodococcus qingshengii (JR3/2-4, 99.7\%), and Rhodococcus fascians (J1-4, 100\%). 

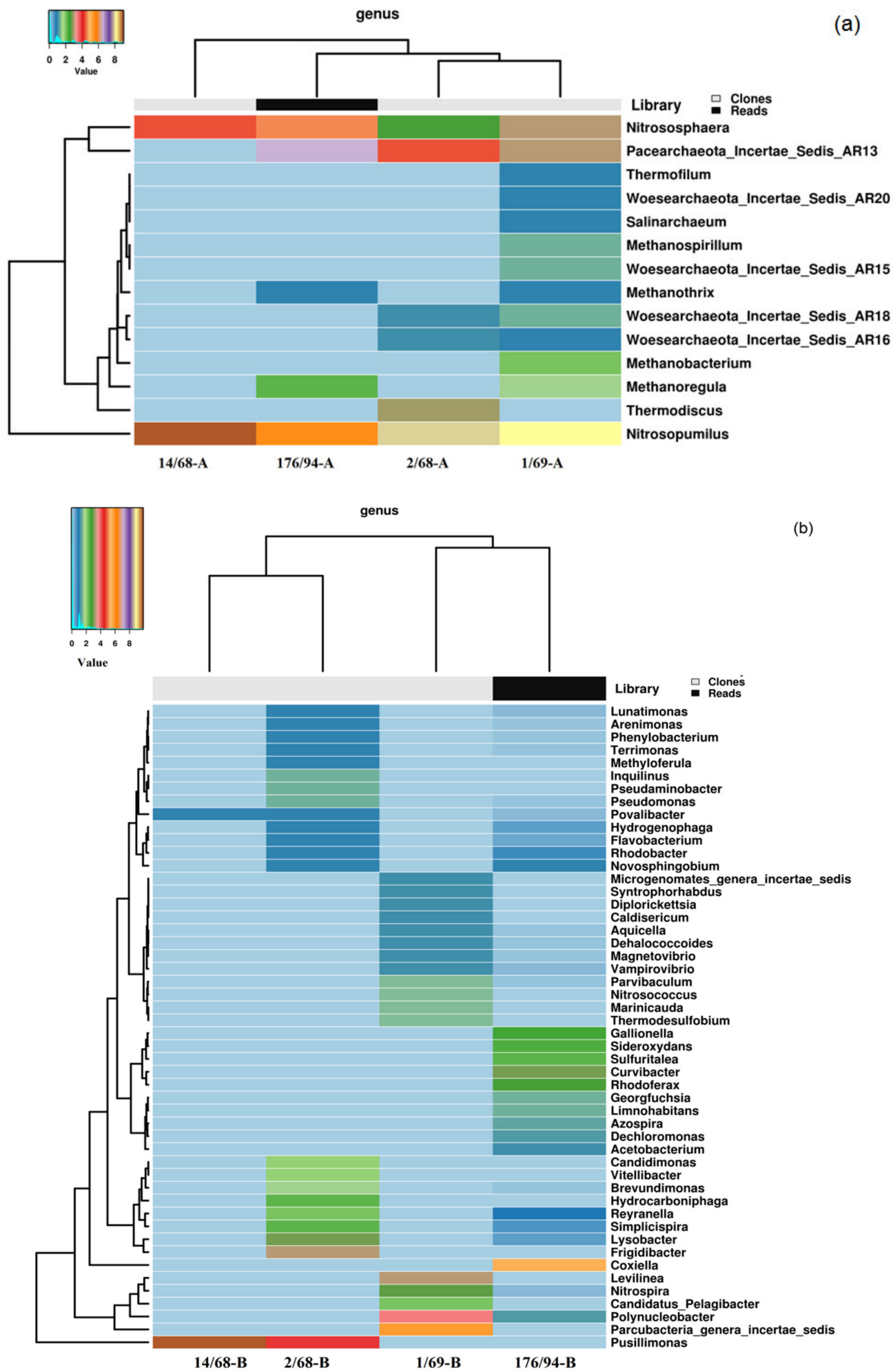

Figure 1. Heatmap analysis of the distribution of the dominant genera of Archaea (a) and bacteria (b) in groundwater samples. The double hierarchical dendrogram shows microbial distribution in these samples. The relative values for microbial genera are marked by colors from blue to brown designating the least abundant to most abundant. Abundance is expressed as the ratio of the number of targeted sequences to the total number of sequences from each groundwater sample.

The 16S rRNA gene sequence similarity of the strains JR1/69-2-13 and JR1/69-3-13 with closely related Pusillimonas species was within the range of 97.6-96.0, and the similarity between strains was 
$98.7 \%$, showing their affiliation to two new species. Phenotypic characteristic and taxonomy of the isolated strains is given in Tables 2 and 3.

Table 2. Taxonomic position of microorganisms isolated from the groundwater at the Karachai area.

\begin{tabular}{|c|c|c|c|c|}
\hline Strain & $\begin{array}{l}\text { Closest Cultivated Microorganism, } \\
\text { Accession No. of } 16 S \text { rRNA Gene }\end{array}$ & $\begin{array}{l}\text { Accession No.* of } \\
\text { 16S rRNA Gene }\end{array}$ & $\begin{array}{c}\text { 16S rRNA } \\
\text { Similarity, } \%\end{array}$ & $\begin{array}{l}\text { Genome } \\
\text { Size, } \mathrm{Mb}\end{array}$ \\
\hline JR1/69-1-13 & Roseomonas aestuarii JC17 ${ }^{\mathrm{T}}$, NR_116913 & MG205609 & 99.6 & 5.2 \\
\hline JR1/69-2-13 & Pusillimonas harenae B201, GQ232740 & MG205613 & 98.6 & 4.3 \\
\hline JR1/69-3-13 & Pusillimonas harenae B201, GQ232740 & MG205614 & 98.5 & 4.5 \\
\hline $\mathrm{J} 1-13 \mathrm{~Tb}$ & Chryseobacterium haifense $\mathrm{H} 38^{\mathrm{T}}$, NR_044167 & MG205639 & 98.2 & $2.8^{* *}$ \\
\hline$J R 3 / 2-4$ & $\begin{array}{c}\text { Rhodococcus qingshengii JCM } 15477^{\mathrm{T}} \\
\text { DQ090961 }\end{array}$ & MG205632 & 99.7 & $7.2 * *$ \\
\hline $\mathrm{J} 1-4$ & $\begin{array}{l}\text { Rhodococcus fascians ATCC } 12974^{\mathrm{T}} \text {, } \\
\text { NR_119126 }\end{array}$ & MG205633 & 100 & $5.8^{* *}$ \\
\hline JR2/2-1 & $\begin{array}{c}\text { Mycolicibacterium iranicum } \mathrm{M} 05^{\mathrm{T}} \text {, } \\
\text { NR_117909 }\end{array}$ & MG205634 & 100 & $6.3^{* *}$ \\
\hline JR43/78-4-13 & Janibacter limosus DSM $11140^{\mathrm{T}}$, NR_026362 & MG205635 & 99.7 & $3.4^{* *}$ \\
\hline JR2/1-6 & $\begin{array}{c}\text { Salinibacterium amurskyense KMM } 3673^{\mathrm{T}} \text {, } \\
\text { AF539697 }\end{array}$ & MG205636 & 98.5 & $2.8^{* *}$ \\
\hline $\mathrm{JR} 3 / 2-13$ & $\begin{array}{c}\text { Microbacterium oxydans DSM } 20578^{\mathrm{T}} \text {, } \\
\text { NR_044931 }\end{array}$ & MG205637 & 99.6 & $3.9^{* *}$ \\
\hline $\mathrm{JR} 1 / 1-8 \mathrm{~b}$ & $\begin{array}{c}\text { Paeniglutamicibacter sulfureus DSM } 20167^{\mathrm{T}} \text {, } \\
\text { NR_026237 }\end{array}$ & MG205638 & 99.3 & $\mathrm{ND}^{* * *}$ \\
\hline
\end{tabular}

* Accession no. for $16 \mathrm{~S}$ rRNA genes of the isolated strains. ${ }^{* *}$ Genome size for the type strain of the species obtained from NCBI database (https://www.ncbi.nlm.nih.gov/genome/). ${ }^{* * *} \mathrm{ND}$, no data.

The cells of the isolates were rod-shaped, ovoid, coccoid, or pleomorphic (Figure 2). The cell size of most strains varied depending on the growth medium and cultivation stage. The formation of small filterable cells was probably the result of limited concentrations of available carbon sources in the groundwater.

The small filterable cells of strains JR2/1-6 and J1-13Tb were $<0.1 \mu \mathrm{m}^{3}$ in volume; the genomes of the closest type strains, S. amurskyense $\mathrm{KMM} 3673^{\mathrm{T}}$ and C. haifense $\mathrm{H} 38^{\mathrm{T}}$, had a small size characteristic for ultra-microbacteria (both $2.8 \mathrm{Mb}$ ) (Tables 2 and 3). However, larger cells were also present in the cultures. Cells of strain JR3/2-13 possessed a volume of $<0.1 \mu \mathrm{m}^{3}$ and retained this volume irrespective of growth conditions, but genome size of the closest type strain Microbacterium oxydans DSM $20578^{\mathrm{T}}$ was $3.9 \mathrm{Mb}$. This value exceeded the $3.5-\mathrm{Mb}$ limit accepted for ultramicrobacteria. Thus, these filterable bacteria are facultative ultramicrobacteria or ultramicroforms. The remaining three strains of filterable Actinobacteria, JR2/2-1, JR43/78-4-13, JR1/1-8b, with a normally large cell size possibly decreased cell size under pronouncedly starvation conditions of the groundwater similar to what was shown for the majority of planktonic bacteria [1]. 
Table 3. Phenotypic characteristic and taxonomy of the strains isolated from groundwater samples.

\begin{tabular}{|c|c|c|c|c|c|c|c|c|c|c|c|}
\hline \multirow{2}{*}{ Characteristic } & \multicolumn{11}{|c|}{ Strain } \\
\hline & JR3/2-13 & $\mathrm{J1-13Tb}$ & JR43/78-4-13 & JR2/1-6 & JR2/2-1 & JR3/2-4 & J1-4 & JR1/1-8b & JR1/69-2-13 & JR1/69-3-13 & JR1/69-1-13 \\
\hline Cells morphology & Rods & Rods, cocci & Cocci, rods & Rods & Rods & Pleomorphic & Pleomorphic & Cocci, rods & Rods & Rods & Coccobacilli \\
\hline Cell size, $\mu \mathrm{m}$ & $\begin{array}{c}0.1-0.2 \times \\
0.4-0.9\end{array}$ & $\begin{array}{c}0.4-0.9 \times \\
1.3-2.5 ; \\
0.3\end{array}$ & $\begin{array}{l}\text { Cocci } 0.3-1.2 \\
\text { rods } 0.9 \times 1.3\end{array}$ & $\begin{array}{c}0.3 \times \\
1.3-2.0\end{array}$ & $\begin{array}{c}0.8-1.5 \times \\
1.6-2.4\end{array}$ & $\begin{array}{c}0.9-1.2 \times \\
1.2-4.7 ; \\
0.9-2.5\end{array}$ & $\begin{array}{c}1.1-1.2 \times \\
1.5-3.1 ; \\
0.9-1.5\end{array}$ & $\begin{array}{l}\text { Cocci } \\
0.7-1.6\end{array}$ & $\begin{array}{c}0.8-1.2 \times \\
1.5-2.1\end{array}$ & $\begin{array}{c}0.7-1.3 \times \\
0.9-2.1\end{array}$ & $\begin{array}{c}1.2-1.6 \times \\
1.5-2.4\end{array}$ \\
\hline Motility & + & - & - & - & - & - & - & - & + & + & + \\
\hline \multicolumn{12}{|l|}{$\begin{array}{l}\text { Substrates for aerobic } \\
\text { growth }\end{array}$} \\
\hline Acetate & + & & $\mathrm{W}$ & + & + & + & + & + & + & + & - \\
\hline Oxalate & - & & & + & - & - & - & - & - & - & - \\
\hline Glucose & + & + & - & + & + & + & + & + & + & + & + \\
\hline Sucrose & + & + & - & + & + & + & + & + & $\mathrm{W}$ & $\mathrm{W}$ & + \\
\hline Ethanol & $\mathrm{W}$ & & & - & + & + & + & $\mathrm{W}$ & - & - & - \\
\hline Alanine & $\mathrm{W}$ & & & + & - & - & - & + & + & - & - \\
\hline Lactate & + & + & & + & - & + & + & $\mathrm{W}$ & + & $\mathrm{W}$ & + \\
\hline Acetate $+\mathrm{Fe}^{3+} \rightarrow \mathrm{Fe}^{2+}$ & - & & - & - & - & - & & - & - & - & + \\
\hline $\begin{array}{c}\text { Acetate }+ \\
\mathrm{NO}_{3}^{-} \rightarrow \mathrm{NO}_{2}^{-}\end{array}$ & - & - & + & - & - & - & W & + & + & + & + \\
\hline Acetate $+\mathrm{NO}_{3}{ }^{-} \rightarrow \mathrm{N}_{2}$ & - & - & - & - & - & - & - & + & + & - & - \\
\hline $\begin{array}{l}\text { Temperature, } \\
\text { range/optimum, }{ }^{\circ} \mathrm{C}\end{array}$ & $5-42 / 30$ & $5-40 / 30-32$ & $4-50 / 28$ & $5-37 / 25-28$ & $13-42 / 35$ & $21-42 / 33$ & $13-35 / 28$ & $28-38 / 28$ & $5-35 / 30$ & $5-35 / 30$ & $13-42 / 30$ \\
\hline $\begin{array}{c}\mathrm{NaCl} \text {, range/optimum } \\
(\%, w / v)\end{array}$ & $0-7 / 0.5-3$ & $0-2 / 0-1.5$ & $0-4$ & $0-10 / 1-2$ & $0-5(7) / 0-2$ & $0-5(7) / 0-2$ & $0-7(9) / 0-3$ & $0-8 / 0.5-2$ & $0-3 / 0.5-1$ & $0-50.5-3$ & $0-3 / 0.5-1$ \\
\hline
\end{tabular}

+ , positive growth; - , negative growth; $\mathrm{W}$, weak reaction. 


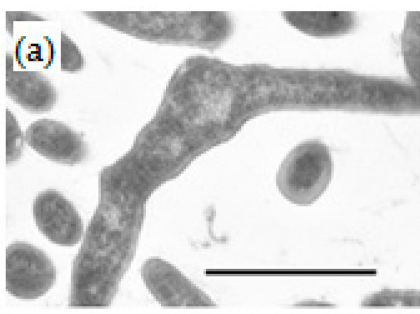

(d)
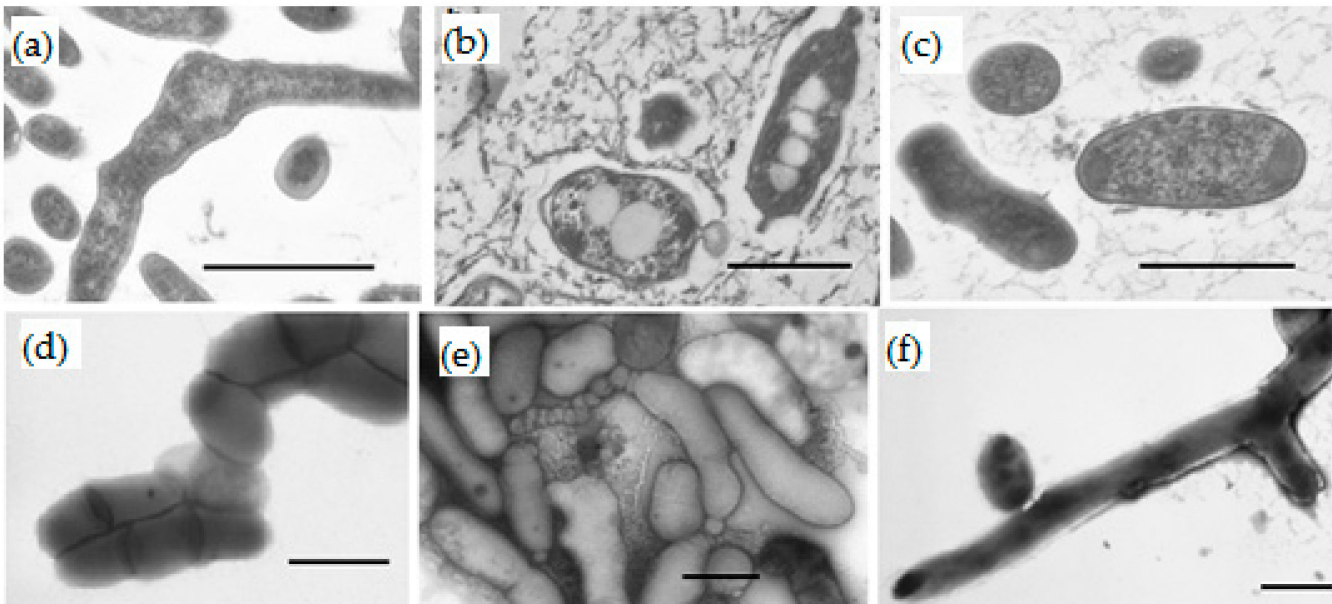

(f)
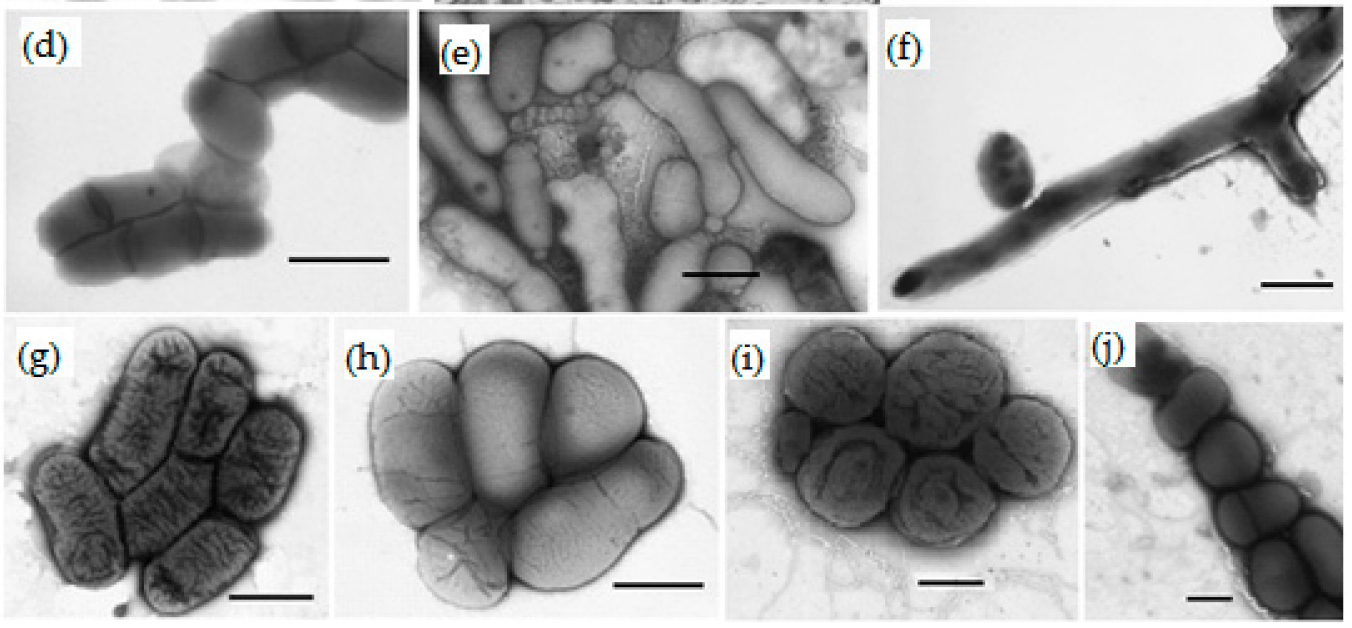

(h)

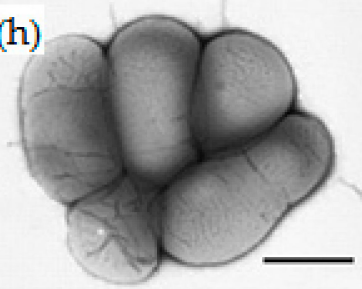

(i)

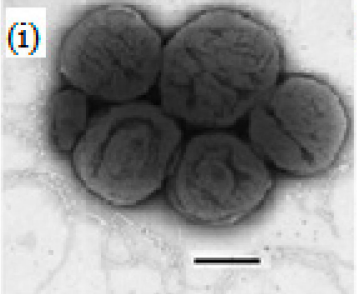

(j)

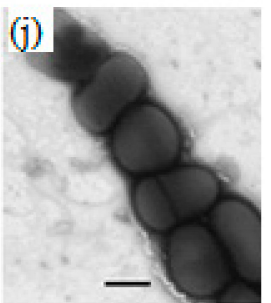

Figure 2. Morphology of the isolated strains as shown by transmission electron microscopy of ultrathin sections (a-c) and negatively stained whole cells $(\mathbf{d}-\mathbf{j})$ : (a) Salinibacterium sp. JR2/1-6; (b) Pusillimonas sp. JR1/69-2-13; (c) Microbacterium oxydans JR3/2-13; (d) Mycobacterium iranicum JR-2/2-1; (e) Chryseobacterium sp. J1-13Tb; (f) Rhodococcus qingshengii JR 3/2-4; (g) Pusillimonas sp. JR1/69-2-13; (h) Pusillimonas sp. JR1/69-3-13; (i) Roseomonas aestuarii JR1/69-1-13; (j) Paeniglutamicibacter sulfureus JR1/1-8b. The cells were grown in TEG medium at $20-22{ }^{\circ} \mathrm{C}$ for $2-3$ days. Scale bars in all panels correspond to $0.5 \mu \mathrm{m}$.

Glöckner and co-workers [50] used group-specific oligonucleotide probes to demonstrate that the cells of most of the hybridized freshwater actinobacteria are very small in situ.

The filterable bacterium Chryseobacterium sp. J1-13Tb had unique morphology. When grown on agarized media, strain J1-13Tb formed beige slimy colonies $2-4 \mathrm{~mm}$ in diameter. The cells were spherical, ovoid, bean-shaped, short rods (coccobacilli), or irregularly shaped rods (Figure 2e). The cells divided either by binary fission or formed small spherical buds laterally or at the poles. The size of spherical and kidney-shaped forms varied from 0.1 to $0.3 \mu \mathrm{m}$; undivided and pleomorpic cells were $0.4-0.9 \mu \mathrm{m}$ in diameter and 1.3-2.5 $\mu \mathrm{m}$ long. Since the volume of small coccoid cells $0.3 \mu \mathrm{m}$ in diameter was $0.014 \mu \mathrm{m}^{3}$, they may be described as nanoforms, which explains their occurrence among filterable bacteria.

All isolates were aerobic organotrophs capable of using acetate, which was present in groundwater, as well as sugars, alcohols, and organic acids (Table 3). Five strains grew anaerobically with acetate, reducing nitrate to nitrite or to dinitrogen. Most strains were psychrotolerant and grew at temperatures of $\sim 10^{\circ} \mathrm{C}$, which was an indication of their adaptation to the environment.

\subsection{Tolerance of the Isolates to Heavy Metals and Ionizing Radiation}

In view of wide occurrence of members of the genus Pusillimonas in radionuclide-contaminated groundwater, their resistance to heavy metals $\left(\mathrm{Zn}^{2+} ; \mathrm{Cr}^{6+} ; \mathrm{Cu}^{2+} ; \mathrm{Cd}^{2+} ;\right.$ and $\left.\mathrm{U}^{6+}\right)$ and $\gamma$-radiation was studied. Roseomonas aestuarii strain JR1/69-1-13 was used for comparison. Both Pusillimonas strains, JR1/69-2-13 and JR1/69-3-13, exhibited high resistance to cadmium, chromium, and uranium (exceeding $400 \mathrm{mg} \mathrm{U}^{6+} \mathrm{L}^{-1}$ ) (Table 4). The lethal chromium concentration $\left(\mathrm{LD}_{100}\right)$ for Pusillimonas sp. JR1/69-3-13 was rather high (400 $\mathrm{mg} \mathrm{L}^{-1}$ ). Roseomonas aestuarii JR1/69-1-13 was less resistant to the tested heavy 
metals (including uranium) than Pusillimonas strains. All three strains were highly resistant ionizing radiation (Figure A3).

Table 4. Tolerance of isolated strains to heavy metals and ionizing radiation.

\begin{tabular}{|c|c|c|c|c|c|c|c|}
\hline \multirow{2}{*}{ Strain } & \multirow{2}{*}{$\begin{array}{l}\mathrm{LD}_{50} \\
\mathrm{LD}_{100}\end{array}$} & \multirow{2}{*}{$\begin{array}{l}\text { Radiation } \\
\text { Dose (kGy) }\end{array}$} & \multicolumn{5}{|c|}{ Maximum Concentration $\left(\mathrm{mg} \mathrm{L}^{-1}\right)$} \\
\hline & & & $\mathrm{Zn}^{2+}$ & $\mathrm{Cr}^{6+}$ & $\mathrm{Cu}^{2+}$ & $\mathrm{Cd}^{2+}$ & $\mathrm{U}^{6+}$ \\
\hline \multirow{2}{*}{ R. aestuarii JR1/69-1-13 } & $\mathrm{LD}_{50}$ & 5.0 & 10 & 25 & 50 & 50 & 10 \\
\hline & $\mathrm{LD}_{100}$ & 15.0 & 100 & 100 & $>200$ & 200 & 100 \\
\hline \multirow{2}{*}{ Pusillimonas sp. JR1/69-2-13 } & $\mathrm{LD}_{50}$ & 1.0 & 50 & 25 & 100 & 100 & 250 \\
\hline & $\mathrm{LD}_{100}$ & 10.0 & 200 & 200 & $>200$ & 300 & $>400$ \\
\hline \multirow{2}{*}{ Pusillimonas sp. JR1/69-3-13 } & $\mathrm{LD}_{50}$ & 1.0 & 50 & 100 & 100 & 100 & 250 \\
\hline & $\mathrm{LD}_{100}$ & 10.0 & 200 & 400 & $>200$ & 300 & $>400$ \\
\hline
\end{tabular}

3.5. Metabolic Potential of Pusillimonas and Roseomonas Strains, as Assessed by Physiology and Genomes Analyses

Members of the genus Pusillimonas, which were numerically predominant among the $16 \mathrm{~S}$ rRNA gene sequences in the libraries from most strongly contaminated water of wells $14 / 68$ and 2/68, were isolated in pure cultures for in-depth investigation. Two Pusillimonas strains, JR1/69-2-13 (=VKM B-3222 $=\mathrm{KCTC} 62614)$ and JR1/69-3-13 (=VKM B-3223 = KCTC 62615), grew within the range of 5-35 ${ }^{\circ} \mathrm{C}$ with the optimum at $30-35^{\circ} \mathrm{C}$, and thus probably were psychrotolerant bacteria. They grew at $\mathrm{pH} 7.0$, in the presence of $0 \%-3 \%$ and $0 \%-5 \%(w / v) ~ N a C l$ with optimums at $1 \%$ and $2 \% \mathrm{NaCl}$, respectively. Carbon substrates utilized for aerobic growth by both strains included D-glucose, D-fructose, D-maltose, sucrose, D-xylose, acetate, $n$-valerate, fumarate, DL-lactate, L-malate, pyruvate, L-phenylalanine, and L-proline. Strain JR1/69-2-13 also utilized L-arabinose, D-mannose, L-rhamnose, D-ribose, butyrate, L-alanine, and gluconate; strain JR1/69-3-13 utilized D-galactose and succinate. Under anaerobic conditions in the medium with acetate strain JR1/69-3-13 reduced nitrate to $\mathrm{N}_{2}$, while strain JR1/69-2-13 was incapable of reducing nitrate, but reduced nitrite to $\mathrm{N}_{2}$.

Genomes of Pusillimonas sp. JR1/69-2-13 and Pusillimonas sp. JR1/69-3-13 were sequenced and annotated with the goal of elucidation of their taxonomic position and identification of the genetic determinants providing for their occurrence in the environment contaminated with radioactive waste [42].

The genome of the strain JR1/69-2-13 consists of 4,307,924 bp and comprises 33 scaffolds, with an overall $G+C$ content of $57.2 \%$. The genome of the strain JR1/69-3-13 consists of 4,541,669 bp and comprises 61 scaffolds, with an overall $G+C$ content of $57.9 \%$. The genomes of the strains JR1/69-2-13 and JR1/69-3-13 were predicted to include 4108 (98.5\%) and $4260(98.6 \%)$ protein-coding genes, respectively. Among the protein-coding genes, $85.0 \%$ and $85.3 \%$, respectively, were assigned to putative functions, and the remaining genes were annotated as hypothetical proteins. The distribution of genes into COG functional categories is summarized in Figure A4.

The genes involved in central carbon metabolism in both strains included a set of genes encoding glycolysis/gluconeogenesis, the Entner-Doudoroff pathway, the pentose phosphate pathway, and the tricarboxylic acid (TCA) cycle. In JR1/69-2-13 genome, the Calvin-Benson cycle of $\mathrm{CO}_{2}$ fixation was revealed, including the large and small subunits of form I Rubisco, Rubisco activase, fructose-1,6-bisphosphatase and phosphoribulokinase (PLC53897-PLC53901), which were absent in the JR1/69-3-13 genome. 
The genomes of both strains encoded the enzymes necessary for assimilatory sulfate reduction, including sulfate adenylyltransferase subunit 1 (PLC54533, PLC49270), sulfate adenylyltransferase subunit 2 (PLC54704, PLC49269), phosphoadenosine phosphosulfate reductase (PLC54534, PLC49268), sulfite reductase alpha subunit (PLC55466, PLC51459), and sulfite reductase beta subunit (PLC55268, PLC51319). Interestingly, JR1/69-2-13 genome harbors the complete set of sulfur-oxidizing genes including soxA (PLC53471), soxB (PLC53691), soxC (PLC53692), soxD (PLC53474), soxX (PLC53470), soxY (PLC53473), and soxZ (PLC53472) for thiosulfate oxidation. Sox multienzyme complex was not revealed in the JR1/69-3-13 genome.

The denitrification gene cluster included the genes predicted to encode the enzymes for sequential reduction of nitrate to dinitrogen gas, consistent with the complete denitrification phenotype of the strain JR1/69-3-13 (Table A3). In the JR1/69-2-13 genome, the genes encoding nitrate reductase were absent, but the genes encoding nitrite reductase (Nir), nitric oxide reductase (Nor), and nitrous oxide reductase (Nos) were revealed.

Strain JR1/69-2-13 reduced selenite under anoxic conditions, and the genes responsible for selenite transport into the cell and selenite reduction were revealed in the genome. Numerous genes responsible for heavy metal tolerance and detoxification were identified in the genome of JR1/69-2-13, including those encoding copper resistance protein $\mathrm{CopB}$, copper chaperone, copper-translocating P-type ATPase, cobalt-zinc-cadmium resistance protein CzcA, mercuric reductase, DNA gyrase subunit A and B involved in fluoroquinolone resistance, various polyols $\mathrm{ABC}$ transporter and DedA protein involved in the uptake of selenate and selenite, an arsenate reductase and mercuric reductase. In the genome of strain JR1/69-2-13, the genes for cobalt-zinc-cadmium resistance protein CzcA, chromate resistance protein $\mathrm{ChrB}$, and the arsenate reductase coding gene were identified. Detection of an arsenate reductase coding gene suggests that the reduction capabilities of both strains are broader than expected.

Our previous study [42] demonstrated that average nucleotide identity (ANI) values of JR1/69-2-13 and JR1/69-3-13 genomes with genomes of Pusillimonas strains were within the range of $77.6 \%-84.5 \%$. These ANI values were below the species border, proposed to be $95 \%-96 \%$ [51]. In silico DNA-DNA hybridization ( $\mathrm{dDDH})$ values against reference genomes of Pusillimonas and Candidimonas strains were within the range of $19.3-28.8$, and also were below the $70 \%$ threshold to differentiate bacterial species [52].

Thus, analysis of genomes of the strains JR1/69-2-13 and JR1/69-3-13 testifies to their belonging to two novel species within the Pusillimonas genus with proposed names 'Pusillimonas nitritireducens' and 'Pusillimonas subterraneus', respectively [42]. The genome sequences of both strains provide an insight into the genomic basis of their resistance to heavy metals and metalloid and ability to survive in nitrate-contaminated groundwater.

Roseomonas aestuarii JR1/69-1-13 (=VKM B-3221) was another strain isolated from the 1/69 groundwater sample. Strain JR1/69-1-13 was a Gram-negative, aerobic chemoorganoheterotrophic bacterium, motile in the early exponential phase, and forming orange pigmented colonies. The strain was able to grow at temperatures ranging from 13 to $42{ }^{\circ} \mathrm{C}$ with an optimum at $35^{\circ} \mathrm{C}$, at pH 7.0-7.5, in the presence of $0 \%-3 \%(w / v) \mathrm{NaCl}$ with an optimum at $0.5 \%-1 \%(w / v) \mathrm{NaCl}$. The strain utilized sugars, amino acids, aromatic compounds, and organic acids. Under anaerobic conditions in the medium with glucose, strain JR1/69-1-13 reduced nitrate to nitrite. The genome of the strain consisted of 5,195,849 bp with an overall G + C content of $71.5 \%$ and contained 4849 genes, of which 4650 were coding DNA sequences, 52 coded tRNAs, and 4 belonged to ncRNAs [43]. Numerous genes responsible for utilization of various organic substrates (sugars, amino acids, organic acids, and chlorinated aromatic compounds), reduction of nitrate to nitrite, and heavy metal tolerance and detoxification were identified in the genome of $R$. aestuarii JR1/69-1-13. 


\section{Discussion}

Use of uranium for fuel production and weapons manufacturing has resulted in widespread environmental contamination in the world [15,53]. Microorganisms are known to affect the migration of both radioactive and non-radioactive waste components [54-56]. Investigation of radionuclide-contaminated environments is therefore important both for determination of the composition and functional activity of microbial communities, and for development of biotechnologies for remediation of contaminated environments.

The present work reports the results of the investigation of the physicochemical and radiochemical conditions and microbial composition in nitrate- and radionuclide-contaminated groundwater samples collected near Lake Karachai (Russia), which has been used for storage of intermediate-level liquid radioactive wastes of PA "Mayak" in the Chelyabinsk region [15]. We also aimed at the isolation and identification of bacteria, including those with ultra-small cell size, and determination of the physiological and genomic characteristics responsible for their adaptation to this environment.

Groundwater samples were collected from the depth of 20-80 $\mathrm{m}$ using the observation (monitoring) wells located at weakly contaminated and strongly contaminated zones. The studied groundwater samples had a high redox potential (Eh from +110 to $+420 \mathrm{mV}$ ), their $\mathrm{pH}$ varied from 6.9 to 8.0. They had higher total mineralization and higher concentrations of nitrate (up to $13.6-42.7 \mathrm{~g} \mathrm{~L}^{-1}$ ), acetate (up to $921 \mathrm{mg} \mathrm{L}^{-1}$ ), and radionuclides (Table 1) than the uncontaminated natural water [48]. Many systems with these contaminants are highly acidic because of the nitric acid contamination. At the Lake Karachai measures were taken to establish the hydrochemical regime promoting radionuclide retention. Acidic solutions were always neutralized. For this purpose, solutions with high concentrations of metal hydroxides (mainly those of aluminum, iron, and manganese) with $\mathrm{pH}>8$ were dumped into the lake until 1985. Soda ash was also added. According to the data of many years, $\mathrm{pH}$ of the water varied from 7.2 to 9.8 with the average value of 8.7 [57].

Cultured aerobic organotrophic and nitrifying bacteria, as well as anaerobic denitrifying and iron-reducing prokaryotes were revealed in the groundwater samples. The numbers of sulfate-reducing bacteria and methanogens, as well as the rates of sulfate reduction and methanogenesis, were low or undetected, probably due to the high redox values and high nitrate concentration (Table 1, Figure A1).

Pyrosequencing of the $16 \mathrm{~S}$ rRNA genes revealed that the share of archaeal sequences in the 176/94 library did not exceed $0.5 \%$, and they belonged to ammonium-oxidizing archaea of the genera Nitrosopumilus and Nitrososphaera (Thaumarchaeota), uncultured Pacearchaeota, and methanogens of the genera Methanoregula and Methanothrix (Euryarchaeota) (Figures 1 and A2a, Table A1). The sequences of Nitrosopumilus and Nitrososphaera were predominant also in the three clone libraries obtained, which showed the presence of the archaea involved in the nitrogen cycle in contaminated groundwater. Ammonium-oxidizing members of the phylum Thaumarchaeota were also revealed in a subsurface radioactive thermal spring, the Franz-Josef-Quelle in Bad Gastein, Austria [58]. Uncultured Pacearchaeota characterized by small cells and small genomes were found in an aquifer amended with acetate at the Colorado River, near Rifle (CO, USA). Castelle and co-workers [13] performed metagenomic analyses of Pacearchaeota found in this aquifer amended with acetate and showed that these archaea were characterized by small cells and small genomes, and "involved in anaerobic carbon and hydrogen metabolism, probably associated with symbiotic and/or fermentation-based lifestyles."

Our results correlate with the data of metagenomic studies of microbial communities from contaminated groundwater (FW106 site) sampled at the Oak Ridge Integrated Field Research Center (OR-IFRC) [59]. At the FW106 site, groundwater was also characterized by circumneutral pH, high concentrations of nitric acid, uranium and other radionuclides, heavy metals, and organic solvents. Microbial diversity in contaminated groundwater decreased significantly, with predominance of Rhodanobacter populations adapted to the combination of stresses at the site, in comparison with more diverse pristine groundwater community having a higher functional and metabolic potential. Moreover, denitrifying bacteria of the genus Rhodanobacter dominated also in groundwater with low $\mathrm{pH}$ at the FW106 site [55]. 
Microbial community in ethanol-amended sediments from Area 1 in Oak Ridge with acidic groundwater ( $\mathrm{pH}$ ranging from 3.0 to 6.8 ) and high concentrations of nitrate, $\mathrm{U}(\mathrm{VI}), \mathrm{Tc}(\mathrm{VII})$, and sulfate was enriched with members of the genus Castellaniella (class Betaproteobacteria), which are capable of nitrate reduction [60]. In another experiment at Area 1, addition of ethanol or glucose and $\mathrm{pH}$ neutralization of initially acidic groundwater with low concentrations of nitrate resulted in an increase of metal-reducing bacteria of the genera Anaeromyxobacter and Geobacter of the Deltaproteobacteria in acidic subsurface sediments [54]. These studies show that nitrate and radionuclides pollution decreases microbial diversity and stimulates growth of the community components best adapted to the conditions of the contaminated habitat $[54,60]$.

The diversity of bacteria was highest in weakly contaminated groundwater from wells 1/69 and 176/94 (Figures $1 \mathrm{~b}$ and A2b, Table A1). Among the sequences revealed in the libraries obtained from groundwater, those of Candidatus Parcubacteria (former OD1, 34.5\% sequences in the 1/69 library), which include bacteria with ultra-small size of cells and reduced metabolic capacities [9], were revealed, as well as the sequences of Pusillimonas, Polynucleobacter, Microbacterium, Chryseobacterium, Elusimicrobium, and 'Candidatus Pelagibacter,' which also include bacteria with small or ultra-small size of the cells (Figure 1b, Table A1). In the samples of highly contaminated groundwater from wells $2 / 68$ and $14 / 68$, members of the genus Pusillimonas predominated $(18.2 \%$ and $97.1 \%$ sequences in the libraries, respectively).

Aerobic chemoorganotrophic ultramicrobacteria of the genus Polynucleobacter, which utilize a narrow range of substrates (acetate, pyruvate, malate, etc.) under aerobic conditions or grow as facultative anaerobes, are known to be common in freshwater environments [61]. Chemoheterotrophic marine bacteria of the SAR11 clade 'Candidatus Pelagibacter ubique' are the Earth's most abundant organisms [22]. Detection of these freshwater and marine bacteria in the studied samples is hardly occasional, considering the broad ranges of salinity and composition in the groundwater affected by Lake Karachai contaminated water.

Bacteria belonging to Dechloromonas, Acinetobacter, uncultured Coxiellaceae, Candidatus Parcubacteria, and undefined Comamonadaceae retrieved in the libraries from groundwater of the Karachai area were also revealed in uranium-contaminated groundwater amended with acetate sampled from an aquifer at Rifle, CO, USA [62]. Genome sequences of Candidatus Parcubacteria (OD1) were reconstructed from groundwater sampled in Rifle [5,6,11]. Sequences of Candidatus Parcubacteria (OD1) were also revealed in groundwater samples in the Karachai area. Thus, similar physicochemical and radiochemical conditions resulted in development of similar microbial communities.

Presence of the sequences of small-celled bacteria in the 16S rRNA gene libraries stimulated their isolation and studying. Using a selective filtration enrichment procedure and long-term incubations at low temperatures as recommended by Carini et al. [22], we isolated the strains Janibacter limosus JR43/78-4-13, Microbacterium oxydans JR3/2-13, Paeniglutamicibacter sulfureus JR1/1-8b, Mycolicibacterium iranicum JR2/2-1, Chryseobacterium sp. J1-13Tb, and Salinibacterium sp. JR2/1-6. Aerobic and denitrifying bacteria Roseomonas aestuarii JR1/69-1-13, Rhodococcus qingshengii JR3/2-4, Rhodococcus fascians J1-4, and Pusillimonas sp. strains JR1/69-2-13 and JR1/69-3-13 were isolated without the filtration stage. Although the strains with ultra-small cell size (below $0.1 \mu^{3}$ ) were isolated (Table 3, Figure 2) cell size of most strains varied depending on the growth medium and cultivation stage. These filterable bacteria were facultative ultra-microbacteria or ultra-microforms. Formation of small filterable cells was probably the result of limited concentrations of available carbon and energy sources in the groundwater. Reduction in cell size caused by nutrient and energy limitations was shown for microorganisms from other oligotrophic habitats [63].

All isolates were aerobic organotrophs utilizing sugars, alcohols, and organic acids, as well as acetate, which was present in groundwater (Table 3). Five strains grew anaerobically with acetate, reducing nitrate to nitrite or to dinitrogen. Numerous stress factors in the studied groundwater (high concentrations of nitrate, radionuclides, and metals, as well as radioactivity) resulted in decreased microbial diversity and predominance of the Pusillimonas population adapted to the conditions of the 
habitat. Pusillimonas strains were resistant to heavy metals $\left(\mathrm{Zn}^{2+}, \mathrm{Cr}^{6+}, \mathrm{Cu}^{2+}, \mathrm{Cd}^{2+}\right.$, and $\left.\mathrm{U}^{6+}\right)$ and $\gamma$-radiation (Table 4, Figure A3). The resistance capability of Pusillimonas and Roseomonas strains to the four heavy metals tested was much higher than that of E. coli. The maximum tolerance concentration to a single heavy metal for E. coli was for $\mathrm{Cd}^{2+}\left(56 \mathrm{mg} \mathrm{L}^{-1}\right), \mathrm{Pb}^{2+}\left(41 \mathrm{mg} \mathrm{L}^{-1}\right), \mathrm{Cu}^{2+}\left(64 \mathrm{mg} \mathrm{L}^{-1}\right)$, and $\mathrm{Zn}^{2+}\left(65 \mathrm{mg} \mathrm{L}^{-1}\right)$ [64]. The maximum tolerance concentrations reported for Pseudomonas, Cupriavidus, Bacillus, and Acinetobacter strains isolated from heavy-metal-polluted soil to $\mathrm{Cd}^{2+}, \mathrm{Pb}^{2+}, \mathrm{Zn}^{2+}$, and $\mathrm{Cu}^{2+}$ were 200, 1600, 600, $265 \mathrm{mg} \mathrm{L}^{-1}$, respectively [65]. Genome sequencing of denitrifying bacteria of the genus Pusillimonas made it possible to determine their taxonomic position and genetic determinants providing for their occurrence in the environment contaminated with radionuclides and nitrates (Tables 2 and A3, Figure A2b).

It should be noted that occurrence of the metal resistance genes is typical of microorganisms from radionuclide-contaminated environments. In plasmidome analysis of groundwater samples from the Oak Ridge Field Research Center (Oak Ridge, TN, USA), which were also characterized by low cell counts but diverse microbial communities, several hundred circular plasmids were identified bearing the genes involved in metal, antibiotic, and phage resistance [66].

\section{Conclusions}

Groundwater microorganisms from the Lake Karachai region used for the disposal of liquid radioactive waste were investigated. Inflow of radioactive waste resulted in decreased microbial diversity in highly contaminated sites compared to the background groundwater samples. High-throughput sequencing and analysis of the clone libraries revealed lower microbial diversity in the most strongly contaminated groundwater and predominance of bacteria of the genera Pusillimonas, Polynucleobacter, Candidatus Pelagibacter, and of the candidate phylum Parcubacteria in the most contaminated groundwater samples; these groups include species with ultra-small cell size. Pure cultures of aerobic organotrophic and denitrifying bacteria isolated from the groundwater samples and identified as members of the genera Janibacter, Microbacterium, Paeniglutamicibacter, Mycolicibacterium, Chryseobacterium, Salinibacterium, Roseomonas, Rhodococcus, and Pusillimonas were facultative ultra-microbacteria or ultra-microforms, possibly formed because of nutrient and energy limitations. The studied bacteria of the genus Pusillimonas, which predominated in the groundwater were resistant to the environment (heavy metals and radioactivity) and capable of reducing nitrate; these findings were supported by their genomes analysis. Bacteria inhabiting groundwater of the Lake Karachai area, including the isolated small-celled strains, are able to grow aerobically or/and anaerobically. Degradation of acetate and organic components of waste and denitrification with formation of $\mathrm{NO}_{2}{ }^{-}, \mathrm{N}_{2} \mathrm{O}$, and $\mathrm{N}_{2}$ are probably the most important microbial geochemical processes in the groundwater studied. A high abundance of denitrifying bacteria and decreasing nitrate concentrations in the groundwater of Lake Karachai area confirm the possible geochemical activity of these bacteria. Removal of nitrates from groundwater in the course of denitrification may result in decreased redox potential, which could stimulate other anaerobic processes, enhancing radionuclide reduction, and may decrease the rate of radionuclide migration.

Author Contributions: Conceptualization, T.N. and K.K.; Formal analysis, D.S., T.T., A.M., N.R. and D.G.; Investigation, T.B., N.K., D.S., R.A., V.K., A.P., A.S. and E.Z.; Methodology, N.R., D.G., S.K. and K.K.; Project administration, S.K., A.N. and K.K.; Resources, S.K. and A.N.; Supervision, T.N.; Writing-original draft, T.N. and D.G.; Writing — review \& editing, T.N. All authors have read and agreed to the published version of the manuscript.

Funding: Russian Science Foundation (grant no. 17-17-01212) supported genome analyses of pure cultures, summarizing of the results and writing of the article. Russian Foundation for Basic Research (grants No. 11-04-92116 and 13-04-92105) supported ecological and radiochemical studies of groundwater. Ministry of Science and Higher Education of the Russian Federation partly funded physiological studies of pure cultures.

Conflicts of Interest: The authors declare no conflict of interest. 


\section{Appendix A}

Table A1. Diversity of the phylotypes of the bacteria and Archaea in 16S rRNA gene libraries of the microorganisms from groundwater.

\begin{tabular}{|c|c|c|c|c|c|c|}
\hline \multirow[t]{2}{*}{ Super-Kingdom } & \multirow[t]{2}{*}{ Phylum, Class } & \multirow{2}{*}{ Genus } & \multicolumn{4}{|c|}{$\begin{array}{c}\text { Share of the Number of Sequences in } \\
\text { the Library * from Well, } \%\end{array}$} \\
\hline & & & $176 / 94$ & $2 / 68$ & $1 / 69$ & $14 / 68$ \\
\hline \multirow{13}{*}{ Archaea } & Crenarchaeota & Thermodiscus & 0 & 8.7 & 0 & 0 \\
\hline & \multirow{5}{*}{ Euryarchaeota } & & 5.8 & 0 & 9.7 & 0 \\
\hline & & Methanobacterium & 0 & 0 & 4.0 & 0 \\
\hline & & Methanoregula & 4.8 & 0 & 2.4 & 0 \\
\hline & & Methanospirillum & 0 & 0 & 1.6 & 0 \\
\hline & & Methanothrix & 1.0 & 0 & 0 & 0 \\
\hline & Pacearchaeota & Incertae_Sedis_AR13 & 42.3 & 19.4 & 8.9 & 0 \\
\hline & \multirow{3}{*}{ Thaumarchaeota } & & 51.9 & 69.9 & 75.8 & 100 \\
\hline & & Nitrosopumilus & 30.7 & 63.4 & 66.9 & 81.0 \\
\hline & & Nitrososphaera & 21.2 & 6.5 & 8.9 & 19.0 \\
\hline & \multirow{3}{*}{ Woesearchaeota } & & 0 & 1.1 & 4.8 & 0 \\
\hline & & Incertae_Sedis_AR15 & 0 & 0 & 2.4 & 0 \\
\hline & & Incertae_Sedis_AR18 & 0 & 1.1 & 1.6 & 0 \\
\hline \multirow{25}{*}{ Bacteria } & Proteobacteria & & 90.7 & 84.0 & 35.2 & 97.1 \\
\hline & \multirow{10}{*}{ Alphaproteobacteria } & & 5.2 & 32.0 & 15.4 & 0 \\
\hline & & Novosphingobium & 1.1 & 0 & 0 & 0 \\
\hline & & Reyranella & 0 & 5.1 & 0 & 0 \\
\hline & & Brevundimonas & 0 & 3.0 & 0 & 0 \\
\hline & & Parvibaculum & 0 & 0 & 2.4 & 0 \\
\hline & & $\begin{array}{l}\text { Candidatus } \\
\text { Pelagibacter }\end{array}$ & 0 & 0 & 4.8 & 0 \\
\hline & & Marinicauda & 0 & 0 & 2.4 & 0 \\
\hline & & Frigidibacter & 0 & 11.1 & 0 & 0 \\
\hline & & Inquilinus & 0 & 2.0 & 0 & 0 \\
\hline & & Pseudaminobacter & 0 & 2.0 & 0 & 0 \\
\hline & \multirow{14}{*}{ Betaproteobacteria } & & 51.5 & 29.0 & 14.3 & 97.1 \\
\hline & & Gallionella & 6.9 & 0 & 0 & 0 \\
\hline & & Curvibacter & 9.2 & 0 & 0 & 0 \\
\hline & & Rhodoferax & 7.9 & 0 & 0 & 0 \\
\hline & & Sulfuritalea & 5.6 & 0 & 0 & 0 \\
\hline & & Limnohabitans & 2.0 & 0 & 0 & 0 \\
\hline & & Dechloromonas & 1.6 & 0 & 0 & 0 \\
\hline & & Polynucleobacter & 1.5 & 0 & 14.3 & 0 \\
\hline & & Sideroxydans & 6.4 & 0 & 0 & 0 \\
\hline & & Simplicispira & 0 & 6.1 & 0 & 0 \\
\hline & & Pusillimonas & 0 & 18.2 & 0 & 97.1 \\
\hline & & Candidimonas & 0 & 4.0 & 0 & 0 \\
\hline & & Georgfuchsia & 2.1 & 0 & 0 & 0 \\
\hline & & Azospira & 1.8 & 0 & 0 & 0 \\
\hline
\end{tabular}


Table A1. Cont.

\begin{tabular}{|c|c|c|c|c|c|c|}
\hline \multirow[t]{2}{*}{ Super-Kingdom } & \multirow[t]{2}{*}{ Phylum, Class } & \multirow[t]{2}{*}{ Genus } & \multicolumn{4}{|c|}{$\begin{array}{c}\text { Share of the Number of Sequences in } \\
\text { the Library * from Well, \% }\end{array}$} \\
\hline & & & $176 / 94$ & $2 / 68$ & $1 / 69$ & $14 / 68$ \\
\hline \multirow{15}{*}{ Bacteria } & \multirow{6}{*}{ Gammaproteobacteria } & & 34.0 & 23.0 & 5.5 & 0 \\
\hline & & $\begin{array}{l}\text { Uncultured } \\
\text { Coxiellaceae }\end{array}$ & 30.9 & 0 & 0 & 0 \\
\hline & & Pseudomonas & 0 & 2.0 & 0 & 0 \\
\hline & & Nitrosococcus & 0 & 0 & 2.4 & 0 \\
\hline & & Lysobacter & 0 & 9.1 & 0 & 0 \\
\hline & & Hydrocarboniphaga & 0 & 6.1 & 0 & 0 \\
\hline & Nitrospirae & Nitrospira & 0 & 0 & 8.3 & 0 \\
\hline & \multirow{2}{*}{ Bacteroidetes } & & 2.1 & 10.0 & 0 & 0 \\
\hline & & Vitellibacter & 0 & 4.0 & 0 & 0 \\
\hline & Parcubacteria & Incertae_sedis & 0 & 0 & 34.5 & 0 \\
\hline & Chloroflexi & Levilinea & 0 & 0 & 10.7 & 0 \\
\hline & \multirow{3}{*}{ Firmicutes } & & 1.4 & 0 & 3.5 & 0 \\
\hline & & Thermodesulfobium & 0 & 0 & 2.4 & 0 \\
\hline & & Acetobacterium & 1.3 & 0 & 0 & 0 \\
\hline & Gemmatimonadetes & Gemmatimonas & 1.0 & 0 & 0 & 0 \\
\hline
\end{tabular}

* The taxonomic groups comprising $\geq 1 \%$ of the total number of Archaea and Bacteria sequences are listed.

Table A2. Diversity indices of the $16 \mathrm{~S}$ rRNA gene sequences of Archaea (A) and bacteria (B) in the libraries obtained by pyrosequencing and/or cloning of $16 \mathrm{~S}$ rRNA genes generated from groundwater samples.

\begin{tabular}{|c|c|c|c|c|c|c|c|c|}
\hline \multirow{2}{*}{ Parameter } & \multicolumn{8}{|c|}{ Libraries from Observation Wells } \\
\hline & \multicolumn{2}{|c|}{$176 / 94$} & \multicolumn{2}{|c|}{$1 / 69 *$} & \multicolumn{2}{|c|}{$2 / 68$} & \multicolumn{2}{|c|}{$14 / 68$} \\
\hline Year of Sampling & \multicolumn{2}{|c|}{2012} & \multicolumn{2}{|c|}{2011} & \multicolumn{2}{|c|}{2010} & \multicolumn{2}{|c|}{2010} \\
\hline Depth of Sampling, $\mathrm{m}$ & \multicolumn{2}{|c|}{60} & \multicolumn{2}{|c|}{44} & \multicolumn{2}{|c|}{80} & \multicolumn{2}{|c|}{80} \\
\hline Library & 176/94-A & 176/94-B & $1 / 69-\mathrm{A}$ & 1/69-B & $2 / 68-A$ & $2 / 68-B$ & 14/68-A & $14 / 68-B$ \\
\hline $\begin{array}{l}\text { Number of sequences in the } \\
\text { library }\end{array}$ & 104 & 17,685 & 104 & 57 & 93 & 99 & 84 & 103 \\
\hline Number of OTUs & 15 & 927 & 14 & 16 & 21 & 60 & 5 & 4 \\
\hline $\begin{array}{l}\text { Shannon-Weaver diversity } \\
\text { index }(\mathrm{H})\end{array}$ & 2.21 & 5.08 & 1.27 & 2.58 & 2.54 & 3.65 & 0.85 & 0.16 \\
\hline Simpson's diversity index (1/S) & 6.11 & 35.50 & 1.97 & 11.0 & 9.0 & 20.80 & 1.70 & 1.10 \\
\hline Evenness & 0.82 & 0.74 & 0.92 & 0.92 & 0.83 & 0.89 & 0.53 & 0.12 \\
\hline $\begin{array}{l}\text { Berger-Parker Dominance } \\
\text { index (D) }\end{array}$ & 0.32 & 0.13 & 0.70 & 0.21 & 0.23 & 0.15 & 0.75 & 0.97 \\
\hline
\end{tabular}

${ }^{*}$ Data from paper Nazina et al. [21]. 
Table A3. Genes for denitrification found in the Pusillimonas sp. JR1/69-2-13 and Pusillimonas sp. JR1/69-3-13 genomes based on the annotation from IMG.

\begin{tabular}{|c|c|c|c|c|c|}
\hline \multirow{2}{*}{ Gene } & \multicolumn{2}{|c|}{ Locus Tag } & \multirow{2}{*}{$\begin{array}{c}\text { GenBank Identifier (pBLAST Best } \\
\text { Hit) }\end{array}$} & \multicolumn{2}{|c|}{$\%$ Identity } \\
\hline & JR1/69-2-13 & JR1/69-3-13 & & JR1/69-2-13 & JR1/69-3-13 \\
\hline narG & - & CR159_07195 & WP_073102996.1 Bordetella petrii & - & 91 \\
\hline narH & - & CR159_07190 & $\begin{array}{c}\text { WP_008166145.1 Achromobacter } \\
\text { arsenitoxydans }\end{array}$ & - & 91 \\
\hline narI & - & CR159_07185 & $\begin{array}{c}\text { WP_084658162.1 Chitinimonas } \\
\text { taiwanensis }\end{array}$ & - & 72 \\
\hline narJ & - & CR159_07180 & $\begin{array}{c}\text { WP_050873229.1 Comamonas } \\
\text { testosteroni }\end{array}$ & - & 81 \\
\hline $\operatorname{nar} X$ & & CR159_07165 & $\begin{array}{c}\text { WP_088588207.1 Achromobacter } \\
\text { marplatensis }\end{array}$ & - & 64 \\
\hline narL & & CR159_07160 & $\begin{array}{c}\text { WP_076411578.1 Achromobacter } \\
\text { xylosoxidans }\end{array}$ & - & 77 \\
\hline narK1 & & CR159_07205 & $\begin{array}{c}\text { WP_072427369.1 Chitinimonas } \\
\text { taiwanensis }\end{array}$ & - & 80 \\
\hline narK2 & & CR159_07200 & WP_028353905.1 Bordetella petrii & - & 80 \\
\hline nirK & CR155_06925 & CR159_13410 & $\begin{array}{c}\text { WP_084135858.1 Candidimonas } \\
\text { bauzanensis }\end{array}$ & 88 & 87 \\
\hline nirk & CR155_06925 & CR159_19240 & $\begin{array}{c}\text { WP_073101649.1 Candidimonas } \\
\text { bauzanensis }\end{array}$ & 87 & 88 \\
\hline norC & CR155_05890 & CR159_19250 & $\begin{array}{c}\text { WP_073101466.1 Candidimonas } \\
\text { bauzanensis }\end{array}$ & 82 & 84 \\
\hline norB & CR155_05895 & CR159_19255 & $\begin{array}{c}\text { WP_084135643.1 Candidimonas } \\
\text { bauzanensis }\end{array}$ & 91 & 90 \\
\hline norQ & CR155_05900 & CR159_19256 & $\begin{array}{c}\text { WP_084135672.1 Candidimonas } \\
\text { bauzanensis }\end{array}$ & 85 & 86 \\
\hline norD & CR155_05905 & CR159_19257 & $\begin{array}{c}\text { WP_073101467.1 Candidimonas } \\
\text { bauzanensis }\end{array}$ & 74 & 76 \\
\hline norZ & CR155_19235 & CR159_02315 & $\begin{array}{c}\text { WP_073106495.1 Candidimonas } \\
\text { bauzanensis }\end{array}$ & 91 & 90 \\
\hline nor $A$ & CR155_19230 & CR159_02310 & $\begin{array}{c}\text { WP_073106498.1 Candidimonas } \\
\text { bauzanensis }\end{array}$ & 83 & 84 \\
\hline norR & CR155_19225 & CR159_02305 & $\begin{array}{c}\text { WP_073106501.1 Candidimonas } \\
\text { bauzanensis }\end{array}$ & 89 & 89 \\
\hline $\operatorname{nos} R$ & CR155_08950 & CR159_05710 & $\begin{array}{c}\text { WP_073103310.1 Candidimonas } \\
\text { bauzanensis }\end{array}$ & 80 & 81 \\
\hline nosZ & CR155_08945 & CR159_05705 & $\begin{array}{c}\text { WP_088147579.1 Achromobacter } \\
\text { denitrificans }\end{array}$ & 89 & 90 \\
\hline nosD & CR155_08940 & CR159_05700 & $\begin{array}{c}\text { WP_073103312.1 Candidimonas } \\
\text { bauzanensis }\end{array}$ & 79 & 80 \\
\hline nos $F$ & CR155_08935 & CR159_05695 & $\begin{array}{c}\text { WP_073103313.1 Candidimonas } \\
\text { bauzanensis }\end{array}$ & 84 & 83 \\
\hline $\operatorname{nos} Y$ & CR155_08930 & CR159_05690 & $\begin{array}{c}\text { WP_073103314.1 Candidimonas } \\
\text { bauzanensis }\end{array}$ & 89 & 88 \\
\hline nosL & CR155_08925 & CR159_05685 & $\begin{array}{c}\text { WP_084135995.1 Candidimonas } \\
\text { bauzanensis }\end{array}$ & 72 & 66 \\
\hline $\operatorname{nos} X$ & CR155_08920 & CR159_05680 & $\begin{array}{c}\text { WP_073103316.1 Candidimonas } \\
\text { bauzanensis }\end{array}$ & 66 & 68 \\
\hline
\end{tabular}




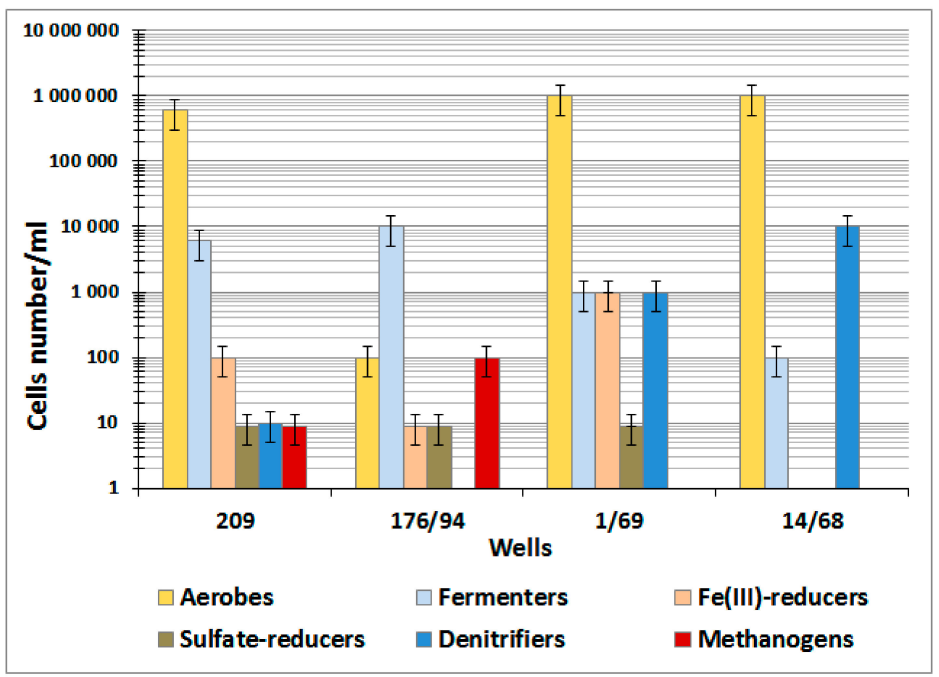

Figure A1. Numbers of aerobic and anaerobic microorganisms in groundwater samples at the Karachai area (well 209, 2011 year of sampling; well 176/94, 2012; wells 1/69 and 14/68, 2013).

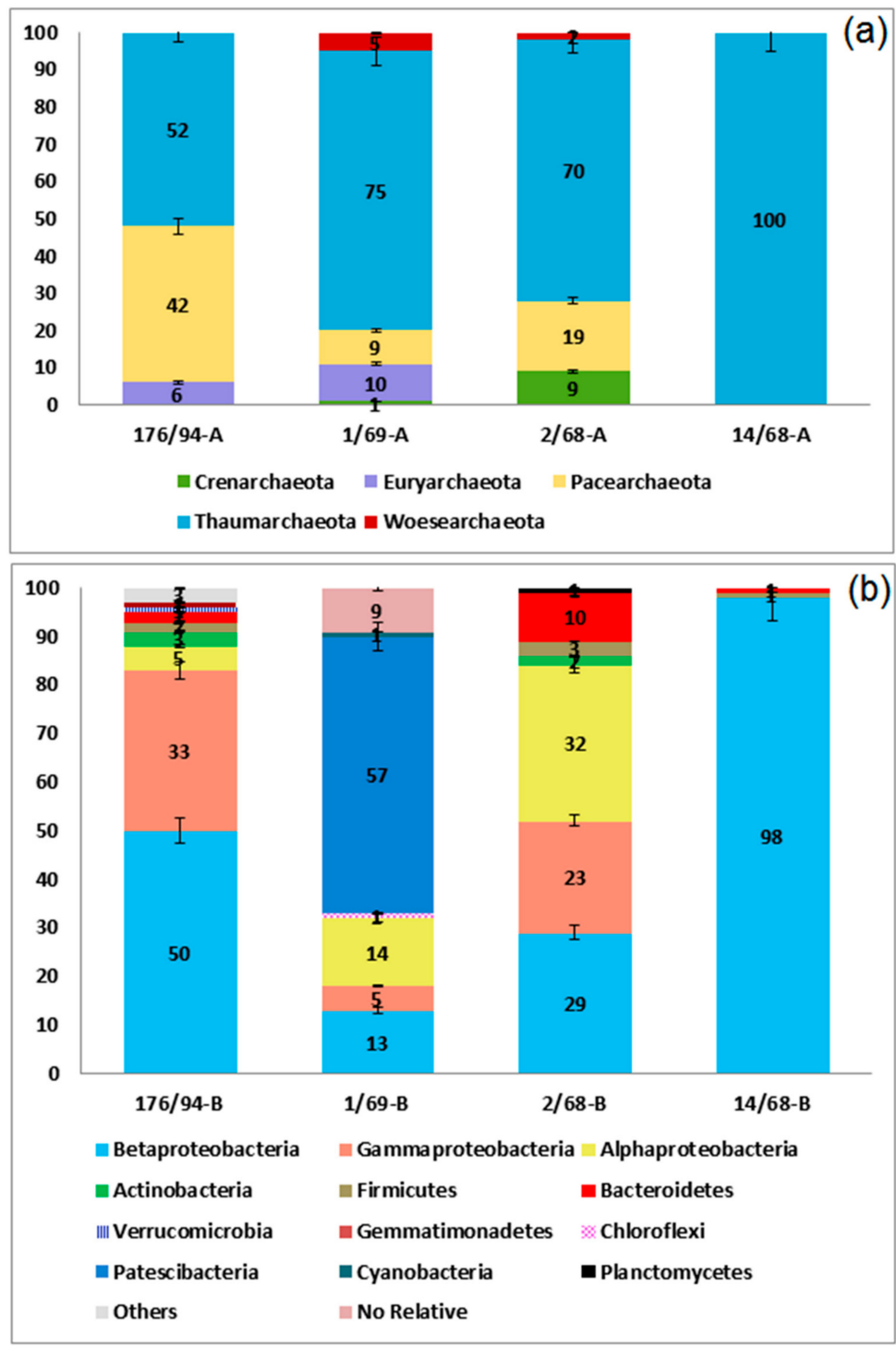

Figure A2. Taxonomic classification of archaeal (a) and bacterial (b) 16S rRNA gene fragments in the libraries from groundwater samples at the phylum level (at the class level for Proteobacteria) using the RDP classifier. 


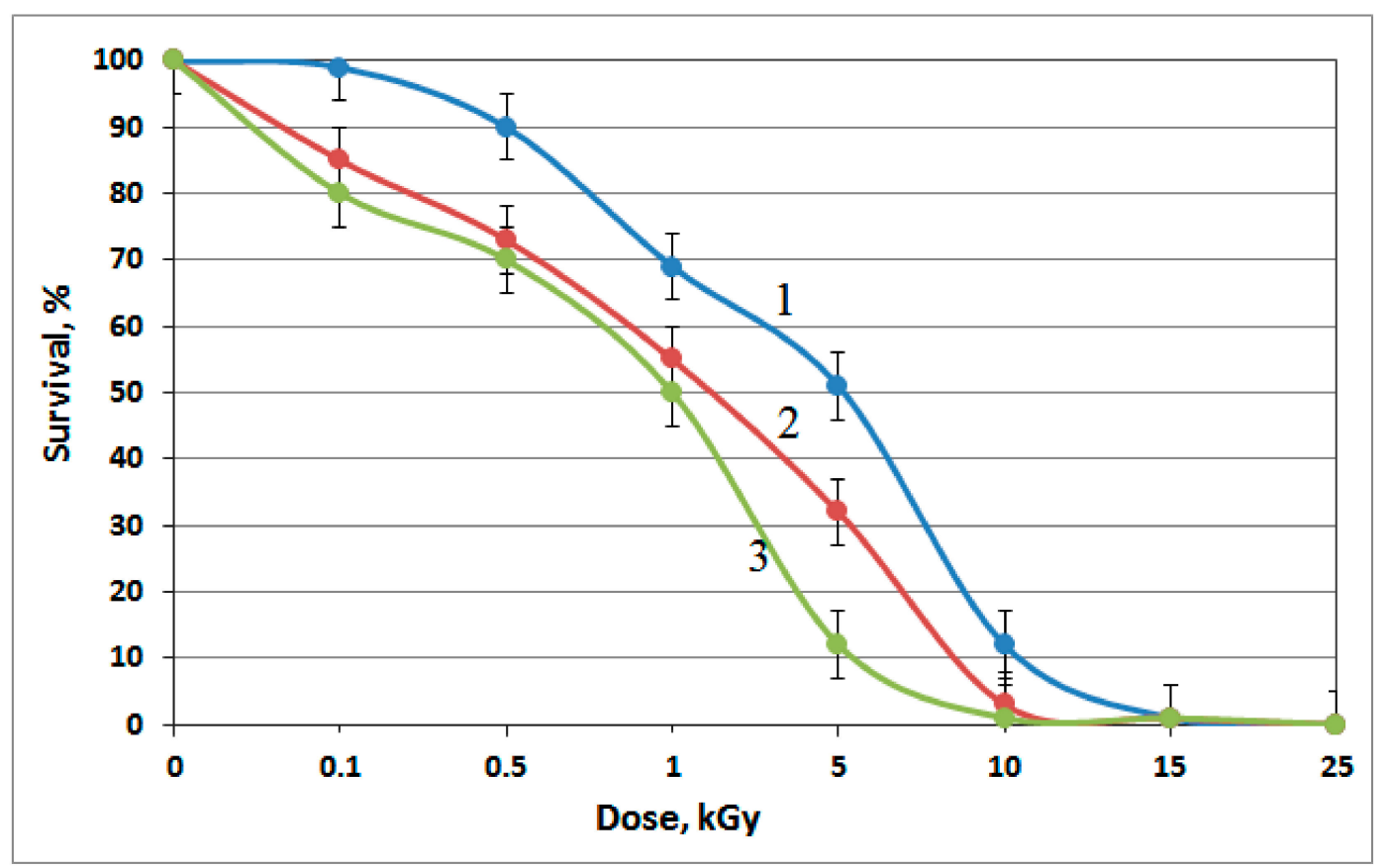

Figure A3. Resistance of the isolates to $\gamma$-radiation: 1, R. aestuarii JR1/69-1-13; 2, Pusillimonas sp. JR1/69-2-13; and 3, Pusillimonas sp. JR1/69-3-13. Error bars represent the standard deviation on the graph. The graph is representative of results obtained on three different replications.

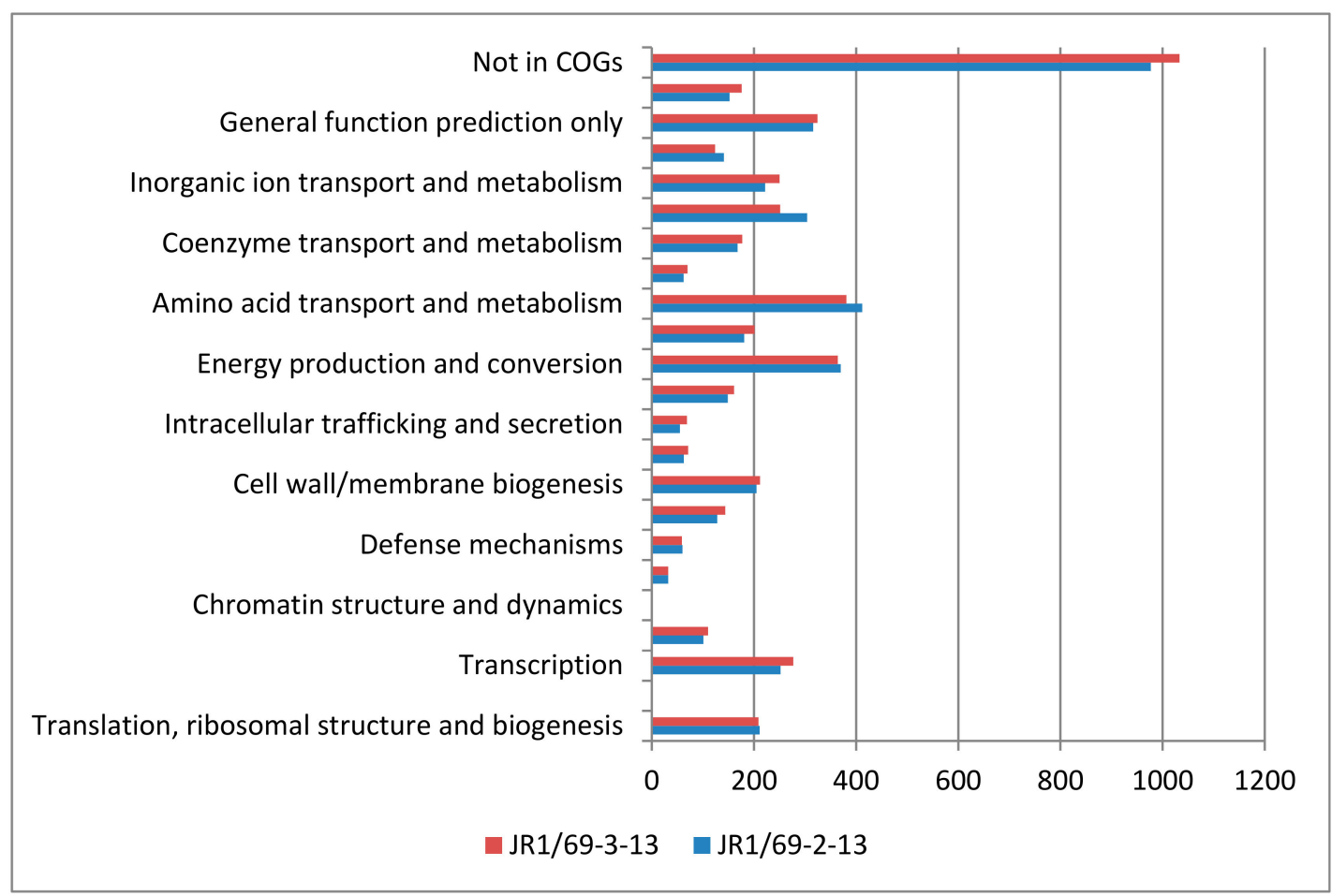

Figure A4. Number of genes assigned to COGs categories in the genomes of Pusillimonas sp. JR1/69-2-13 and Pusillimonas sp. JR1/69-3-13. 


\section{References}

1. Morita, R.Y. Starvation and miniaturisation of heterotrophs, with special emphasis on maintenance of the starved viable state. In Bacteria in Their Natural Environment; Fletcher, M., Floodgate, G.D., Eds.; Academic Press: London, UK, 1985; pp. 111-130.

2. Duda, V.I. Ultramicrobacteria. In Els; John Wiley \& Sons Ltd.: Chichester, UK, 2011; pp. 1-15. [CrossRef]

3. Schut, F.; Prins, R.A.; Gottschal, J.C. Oligotrophy and pelagic marine bacteria: Facts and fiction. Aquat. Microb. Ecol. 1997, 12, 177-202. [CrossRef]

4. Ghiorse, W.C.; Wilson, J.T. Microbial ecology of the terrestrial subsurface. Adv. Appl. Microbiol. 1988, 33, 107-172. [PubMed]

5. Wrighton, K.C.; Thomas, B.C.; Sharon, I.; Miller, C.S.; Castelle, C.J.; VerBerkmoes, N.C.; Wilkins, M.J.; Hettich, R.; Lipton, M.S.; Williams, K.; et al. Fermentation, hydrogen, and sulfur metabolism in multiple uncultivated bacterial phyla. Science 2012, 337, 1661-1665. [CrossRef]

6. Kantor, R.S.; Wrighton, K.C.; Handley, K.M.; Sharon, I.; Hug, L.A.; Castelle, C.J.; Thomas, B.C.; Banfield, J.F. Small genomes and sparse metabolisms of sediment-associated bacteria from four candidate phyla. MBio 2013, 4, e00708-e00713. [CrossRef] [PubMed]

7. Miyoshi, T.; Iwatsuki, T.; Naganuma, T. Phylogenetic characterization of $16 \mathrm{~S}$ rRNA gene clones from deep groundwater microorganisms that pass through 0.2-micrometer-pore-size filters. Appl. Environ. Microbiol. 2005, 71, 1084-1088. [CrossRef] [PubMed]

8. Harris, J.K.; Kelley, S.T.; Pace, N.R. New perspective on uncultured bacterial phylogenetic division OP11. Appl. Environ. Microbiol. 2004, 70, 845-849. [CrossRef] [PubMed]

9. Rinke, C.; Schwientek, P.; Sczyrba, A.; Ivanova, N.N.; Anderson, I.J.; Cheng, J.F.; Darling, A.; Malfatti, S.; Swan, B.K.; Gies, E.A.; et al. Insights into the phylogeny and coding potential of microbial dark matter. Nature 2013, 499, 431-437. [CrossRef]

10. Zachara, J.M.; Long, P.E.; Bargar, J.; Davis, J.A.; Fox, P.; Fredrickson, J.K.; Freshley, M.D.; Konopka, A.E.; Liu, C.; McKinley, J.P.; et al. Persistence of uranium groundwater plumes: Contrasting mechanisms at two DOE sites in the groundwater-river interaction zone. J. Contam. Hydrol. 2013, 147, 45-72. [CrossRef]

11. Nelson, W.C.; Stegen, J.C. The reduced genomes of Parcubacteria (OD1) contain signatures of a symbiotic lifestyle. Front. Microbiol. 2015, 6, 713. [CrossRef]

12. May, H.D.; Sowers, K.R. "Dehalobium chlorocoercia" DF-1-from Discovery to Application. In Organohalide-Respiring Bacteria; Adrian, L., Löffler, F., Eds.; Springer: Berlin/Heidelberg, Germany, 2016. [CrossRef]

13. Castelle, C.J.; Wrighton, K.C.; Thomas, B.C.; Hug, L.A.; Brown, C.T.; Wilkins, M.J.; Frischkorn, K.R.; Tringe, S.G.; Singh, A.; Markillie, L.M.; et al. Genomic expansion of domain archaea highlights roles for organisms from new phyla in anaerobic carbon cycling. Curr. Biol. 2015, 25, 690-701. [CrossRef]

14. Nazina, T.N.; Luk'yanova, E.A.; Zakharova, E.V.; Konstantinova, L.I.; Kalmykov, S.N.; Poltaraus, A.B.; Zubkov, A.A. Microorganisms in a disposal site for liquid radioactive wastes and their influence on radionuclides. Geomicrobiol. J. 2010, 27, 473-486. [CrossRef]

15. Rybal'chenko, A.I.; Pimenov, M.K.; Kostin, P.P.; Balukova, V.D.; Nosukhin, A.V.; Mikerin, E.I.; Egorov, N.N.; Kaimin, E.P.; Kosareva, I.M.; Kurochkin, V.M. Deep Injection Disposal of Liquid Radioactive Waste in Russia; Battelle Press: Columbus, OH, USA, 1998; p. 206.

16. Novikov, A.P.; Pavlotskaya, F.I.; Goryachenkova, T.A.; Posokhov, A.K.; Kazinskaya, I.E.; Emel'yanov, V.V. Radionuclide content in undeground waters from observation wells around Karachai Lake. Radiokhimiya 1998, 40, 484-490.

17. Samsonova, L.M.; Drozhko, E.G. Migration of high-density industrial waste solutions through fresh groundwaters. In Deep Injection Disposal of Hazardous and Industrial Waste: Scientific and Engineering Aspects; Apps, J.A., Tsang, C.-F., Eds.; Academic Press: Cambridge, MA, USA, 1996; Chapter 41; pp. 669-680.

18. Senko, J.M.; Istok, J.D.; Suflita, J.M.; Krumholz, L.R. In-situ evidence for uranium immobilization and remobilization. Environ. Sci. Technol. 2002, 36, 1491-1496. [CrossRef] [PubMed]

19. Wu, W.-M.; Carley, J.; Green, S.J.; Luo, J.; Kelly, S.D.; Nostrand, J.; Lowe, K.; Mehlhorn, T.; Carroll, S.; Boonchayanant, B.; et al. Effects of nitrate on the stability of uranium in a bioreduced region of the subsurface. Environ. Sci. Technol. 2010, 44, 5104-5111. [CrossRef] 
20. Rumynin, V.G. Radioactive brine migration at the Lake Karachai site (South Urals, Russian Federation). In Subsurface Solute Transport Models and Case Histories. Theory and Applications of Transport in Porous Media; Springer: Dordrecht, The Netherlands, 2011; Volume 25. [CrossRef]

21. Nazina, T.N.; Babich, T.L.; Kostryukova, N.K.; Sokolova, D.S.; Abdullin, R.R.; Tourova, T.P. Microbial diversity and possible activity in nitrate- and radionuclide-contaminated groundwater. In Behavior of Radionuclides in the Environment I. Function of Particles in Aquatic System; Kato, K., Kalmykov, S.N., Konoplev, A., Eds.; Springer-Nature: Tokyo, Japan, 2020; Volume I, Chapter 2; ISBN 978-981-15-0678-9.

22. Carini, P.; Steindler, L.; Beszteri, S.; Giovannoni, S.J. Nutrient requirements for growth of the extreme oligotroph 'Candidatus Pelagibacter ubique' HTCC1062 on a defined medium. ISME J. 2012, 7, 592-602. [CrossRef]

23. Smibert, R.M.; Krieg, N.R. Phenotypic characterization. In Methods for General and Molecular Bacteriology; Gerhardt, P., Murray, R.G.E., Wood, W.A., Krieg, N.R., Eds.; ASM Press: Washington, DC, USA, 1994; pp. 607-654.

24. Reynolds, E.S. The use of lead citrate at high $\mathrm{pH}$ as an electron-opaque stain in electron microscopy. J. Cell. Biol. 1963, 17, 208-212. [CrossRef]

25. Nazina, T.N.; Shestakova, N.M.; Grigor'yan, A.A.; Mikhailova, E.M.; Tourova, T.P.; Poltaraus, A.B.; Feng, C.; Ni, F.; Belyaev, S.S. Phylogenetic diversity and activity of anaerobic microorganisms of high-temperature horizons of the Dagang oil field P R China. Microbiology 2006, 75, 55-65. [CrossRef]

26. Katoh, K.; Toh, H. Recent developments in the MAFFT multiple sequence alignment program. Brief Bioinform. 2008, 9, 286-298. [CrossRef]

27. Trüper, H.G.; Schlegel, H.G. Sulfur metabolism in Thiorhodaceae. I. Quantitative measurements on growing cells of Chromatium okenii. J. Microbiol. Serol. 1964, 30, 321-323.

28. Garrett, R.H.; Nason, A. Further purification and properties of Neurospora nitrate reductase. J. Biol. Chem. 1969, 244, 2870-2882.

29. Safonov, A.V.; Babich, T.L.; Sokolova, D.S.; Grouzdev, D.S.; Tourova, T.P.; Poltaraus, A.B.; Zakharova, E.V.; Merkel, A.Y.; Novikov, A.P.; Nazina, T.N. Microbial community and in situ bioremediation of groundwater by nitrate removal in the zone of a radioactive waste surface repository. Front. Microbiol. 2018, 9, 1985. [CrossRef] [PubMed]

30. Myasoedov, B.F.; Novikov, A.P. Radiochemical procedures for speciation of actinides in the environment. Methodology and data obtained in contaminated by radionuclides regions of Russia. In Proceedings of the Speciation Work Shop, Tokai-Mura, Japan, 25-28 October 1999; pp. 3-21.

31. Nazina, T.N.; Kosareva, I.M.; Petrunyaka, V.V.; Savushkina, M.K.; Kudriavtsev, E.G.; Lebedev, V.A.; Ahunov, V.D.; Revenko Yu, A.; Khafizov, R.R.; Osipov, G.A.; et al. Microbiology of groundwaters from the deep repository of liquid radioactive wastes Severnyi. FEMS Microbiol. Ecol. 2004, 49, 97-107. [CrossRef] [PubMed]

32. Wang, H.; Cheng, H.; Wang, F.; Wei, D.; Wang, X. An improved 3-(4,5-dimethylthiazol-2-yl)-2,5-diphenyl tetrazolium bromide (MTT) reduction assay for evaluating the viability of Escherichia coli cells. J. Microbiol. Meth. 2010, 82, 330-333. [CrossRef] [PubMed]

33. Plakunov, V.K.; Mart'yanov, S.V.; Teteneva, N.A.; Zhurina, M.V. A universal method for quantitative characterization of growth and metabolic activity of microbial biofilms in static models. Microbiology 2016, 85, 509-513. [CrossRef]

34. Lane, D.J. 16S/23S rRNA sequencing. In Nucleic Acid Techniques in Bacterial Systematics; Stackebrandt, E., Goodfellow, M., Eds.; John Wiley \& Sons: New York, NY, USA, 1991; pp. 115-175.

35. Edwards, U.; Rogall, T.; Bloeker, H.; Ende, M.D.; Boeettge, E.C. Isolation and direct complete nucleotide determination of entire genes, characterization of gene coding for 16S ribosomal RNA. Nucleic Acids Res. 1989, 17, 7843-7853. [CrossRef]

36. Großkopf, R.; Janssen, P.H.; Liesack, W. Diversity and structure of the methanogenic community in anoxic rice paddy soil microcosms as examined by cultivation and direct 16S rRNA gene sequence retrieval. Appl. Environ. Microbiol. 1998, 64, 960-969. [CrossRef]

37. Kolganova, T.V.; Kuznetsov, B.B.; Tourova, T.P. Selection and testing of oligonucleotide primers for amplification sequencing of archaeal 16S rRNA genes. Microbiology 2002, 71, 243-246. [CrossRef] 
38. Cole, J.R.; Wang, Q.; Cardenas, E.; Fish, J.; Chai, B.; Farris, R.J.; Kulaam-Syed-Mohideen, A.S.; McGarrell, D.M.; Marsh, T.; Garrity, G.M.; et al. The Ribosomal Database Project: Improved alignments and new tools for rRNA analysis. Nucleic Acids Res. 2009, 37, D141-D145. [CrossRef]

39. Caporaso, J.G.; Kuczynski, J.; Stombaugh, J.; Bittinger, K.; Bushman, F.D.; Costello, E.K.; Fierer, N.; Peña, A.G.; Goodrich, J.K.; Gordon, J.I.; et al. QIIME allows analysis of high-throughput community sequencing data. Nat. Methods. 2010, 7, 335-336. [CrossRef]

40. Edgar, R.C. Search and clustering orders of magnitude faster than BLAST. Bioinformatics 2010, 26, $2460-2461$. [CrossRef]

41. Metsalu, T.; Vilo, J. ClustVis: A web tool for visualizing clustering of multivariate data using Principal Component Analysis and heatmap. Nucleic Acids Res. 2015, 43, W566-W570. [CrossRef] [PubMed]

42. Grouzdev, D.S.; Tourova, T.P.; Babich, T.L.; Shevchenko, M.A.; Sokolova, D.S.; Abdullin, R.R.; Poltaraus, A.B.; Toshchakov, S.V.; Nazina, T.N. Whole-genome sequence data and analysis of type strains 'Pusillimonas nitritireducens' and 'Pusillimonas subterraneus' isolated from nitrate- and radionuclide-contaminated groundwater in Russia. Data Brief 2018, 21, 882-887. [CrossRef] [PubMed]

43. Grouzdev, D.S.; Babich, T.L.; Tourova, T.P.; Sokolova, D.S.; Abdullin, R.R.; Poltaraus, A.B.; Schevchenko, M.A.; Toshchakov, S.V.; Nazina, T.N. Draft genome sequence of Roseomonas aestuarii strain JR1/69-1-13 isolated from nitrate- and radionuclide-contaminated groundwater in Russia. Genome Announc. 2018, 6, e00583-18. [CrossRef] [PubMed]

44. Tatusova, T.; DiCuccio, M.; Badretdin, A.; Chetvernin, V.; Ciufo, S.; Li, W. Prokaryotic genome annotation pipeline. In The NCBI Handbook [Internet], 2nd ed.; NCBI: Bethesda, MD, USA, 2013. Available online: http://www.ncbi.nlm.nih.gov/books/NBK174280 (accessed on 10 December 2013).

45. Aziz, R.K.; Bartels, D.; Best, A.A.; DeJongh, M.; Disz, T.; Edwards, R.A.; Formsma, K.; Gerdes, S.; Glass, E.M.; Kubal, M.; et al. The RAST server: Rapid annotations using subsystems technology. BMC Genomics. 2008, 9, 75. [CrossRef]

46. Markowitz, V.M.; Mavromatis, K.; Ivanova, N.N.; Chen, I.M.A.; Chu, K.; Kyrpides, N.C. IMG ER: A system for microbial genome annotation expert review and curation. Bioinformatics 2009, 25, 2271-2278. [CrossRef]

47. Pal, C.; Bengtsson-Palme, J.; Rensing, C.; Kristiansson, E.; Larsson, D.G.J. BacMet: Antibacterial biocide and metal resistance genes database. Nucleic Acids Res. 2014, 42, D737-D743. [CrossRef]

48. Solodov, I.N.; Zotov, A.V.; Khoteev, A.D. Geochemistry of natural and contaminated underground waters in fissured bed bedbedrocks of the Lake Karachai area. Appl. Geochem. 1998, 13, 921-939. [CrossRef]

49. Kim, M.; Oh, H.S.; Park, S.C.; Chun, J. Towards a taxonomic coherence between average nucleotide identity and 16S rRNA gene sequence similarity for species demarcation of prokaryotes. Int. J. Syst. Evol. Microbiol. 2014, 64, 346-351. [CrossRef]

50. Glöckner, F.O.; Zaichikov, E.; Belkova, N.; Denissova, L.; Pernthaler, J.; Pernthaler, A.; Amann, R. Comparative 16S rRNA analysis of lake bacterioplankton reveals globally distributed phylogenetic clusters including an abundant group of Actinobacteria. Appl. Environ. Microbiol. 2000, 66, 5053-5065. [CrossRef]

51. Konstantinidis, K.T.; Ramette, A.; Tiedje, J.M. The bacterial species definition in the genomic era. Philos. Trans. R. Soc. Lond. B Biol. Sci. 2006, 361, 1929-1940. [CrossRef]

52. Meier-Kolthoff, J.P.; Auch, A.F.; Klenk, H.-P.; Göker, M. Genome sequence-based species delimitation with confidence intervals and improved distance functions. BMC Bioinform. 2013, 14, 60. [CrossRef]

53. Wall, J.D.; Krumholz, L.R. Uranium reduction. Annu. Rev. Microbiol. 2006, 60, 149-166. [CrossRef]

54. North, N.; Dollhopf, S.L.; Petrie, L.; Istok, J.D.; Balkwill, D.L.; Kostka, J.E. Change in bacterial community structure during in situ biostimulation of subsurface sediment cocontaminated with uranium and nitrate. Appl. Environ. Microbiol. 2004, 70, 4911-4920. [CrossRef]

55. Green, S.J.; Prakash, O.; Jasrotia, P.; Overholt, W.A.; Cardenas, E.; Hubbard, D.; Tiedje, J.M.; Watson, D.B.; Schadt, C.W.; Brooks, S.C.; et al. Denitrifying bacteria from the genus Rhodanobacter dominate bacterial communities in the highly contaminated subsurface of a Nuclear Legacy Waste Site. Appl. Environ. Microbiol. 2012, 78, 1039-1047. [CrossRef]

56. Newsome, L.; Morris, K.; Lloyd, J.R. The biogeochemistry and bioremediation of uranium and other priority radionuclides. Chem. Geol. 2014, 363, 164-184. [CrossRef] 
57. Alexakhin, A.I.; Glagolev, A.V.; Drozhko, E.G.; Zinin, A.I.; Zinina, G.A.; Ivanov, I.A.; Mokrov, Y.G.; Orlova, E.I.; Samsonov, B.G.; Samsonova, L.M.; et al. Reservoir-9—Storage of Liquid Radioactive Waste and Its Impact on the Geological Environment; Drozhko, E.G., Samsonov, B.G., Eds.; Atomic Energy Agency: Moscow, Russia, 2007; p. 250. ISBN 978-5-9901363-1-1.

58. Weidler, G.W.; Gerbl, F.W.; Stan-Lotter, H. Crenarchaeota and their role in the nitrogen cycle in a subsurface radioactive thermal spring in the Austrian Central Alps. Appl. Environ. Microbiol. 2008, 74, 5934-5942. [CrossRef]

59. Hemme, C.L.; Tu, Q.; Shi, Z.; Qin, Y.; Gao, W.; Deng, Y.; Nostrand, J.D.; Wu, L.; He, Z.; Chain, P.S.; et al. Comparative metagenomics reveals impact of contaminants on groundwater microbiomes. Front. Microbiol. 2015, 6, 1205. [CrossRef]

60. Spain, A.M.; Peacock, A.D.; Istok, J.D.; Elshahed, M.S.; Najar, F.Z.; Roe, B.A.; White, D.C.; Krumholz, L.R. Identification and isolation of a Castellaniella species important during biostimulation of an acidic nitrateand uranium-contaminated aquifer. Appl. Environ. Microbiol. 2007, 73, 4892-4904. [CrossRef]

61. Hahn, M.W. Isolation of strains belonging to the cosmopolitan Polynucleobacter necessarius cluster from freshwater habitats located in three climatic zones. Appl. Environ. Microbiol. 2003, 69, 5248-5254. [CrossRef]

62. Wrighton, K.C.; Castelle, C.J.; Wilkins, M.J.; Hug, L.A.; Sharon, I.; Thomas, B.C.; Handley, K.M.; Mullin, S.W.; Nicora, C.D.; Singh, A.; et al. Metabolic interdependencies between phylogenetically novel fermenters and respiratory organisms in an unconfined aquifer. ISME J. 2014, 8, 1452-1463. [CrossRef]

63. Lever, M.A.; Rogers, K.L.; Lloyd, K.G.; Overmann, J.; Schink, B.; Thauer, R.K.; Tori, M.; Hoehler, T.M.; Jørgensen, B.B. Life under extreme energy limitation: A synthesis of laboratory- and field-based investigations. FEMS Microbiol. Rev. 2015, 39, 688-728. [CrossRef] [PubMed]

64. Nies, D.H. Microbial heavy-metal resistance. Appl. Microbiol. Biotechnol. 1999, 51, 730-750. [CrossRef] [PubMed]

65. Jiang, J.; Pan, C.; Xiao, A.; Yang, X.; Zhang, G. Isolation, identification, and environmental adaptability of heavy-metal-resistant bacteria from ramie rhizosphere soil around mine refinery. 3 Biotech. 2017, 7, 5. [CrossRef] [PubMed]

66. Kothari, A.; Wu, Y.-W.; Chandonia, J.-M.; Charrier, M.; Rajeev, L.; Rocha, A.M.; Joyner, D.C.; Hazen, T.C.; Singer, S.W.; Mukhopadhyay, A. Large circular plasmids from groundwater plasmidomes span multiple incompatibility groups and are enriched in multimetal resistance genes. MBio 2019, 10, e02899-18. [CrossRef]

(C) 2020 by the authors. Licensee MDPI, Basel, Switzerland. This article is an open access article distributed under the terms and conditions of the Creative Commons Attribution (CC BY) license (http://creativecommons.org/licenses/by/4.0/). 